\title{
$\begin{array}{r}\text { WAGENINGEN } \\ \hline\end{array}$
}

Fish welfare in capture fisheries: A review of injuries and mortality

Veldhuizen, L. J. L., Berentsen, P. B. M., de Boer, I. J. M., van de Vis, J. W., \& Bokkers, E. A. M.

This is a "Post-Print" accepted manuscript, which has been published in "Fisheries Research"

This version is distributed under a non-commercial no derivatives Creative Commons (c) (1) @) ( 9 (CC-BY-NC-ND) user license, which permits use, distribution, and reproduction in any medium, provided the original work is properly cited and not used for commercial purposes. Further, the restriction applies that if you remix, transform, or build upon the material, you may not distribute the modified material.

Please cite this publication as follows:

Veldhuizen, L. J. L., Berentsen, P. B. M., de Boer, I. J. M., van de Vis, J. W., \& Bokkers, E. A. M. (2018). Fish welfare in capture fisheries: A review of injuries and mortality. Fisheries Research, 204, 41-48. DOI: 10.1016/j.fishres.2018.02.001

You can download the published version at:

https://doi.org/10.1016/j.fishres.2018.02.001 


\section{Fish welfare in capture fisheries: a review of injuries and mortality}

\section{Abstract}

4 Concerns about the welfare of production animals have extended from farm animals to fish, but 5 an overview of the impact of especially capture fisheries on fish welfare is lacking. This review 6 provides a synthesis of 85 articles, which demonstrates that research interest in fish welfare in 7 capture fisheries has increased over time and that research has focused more on trawls and 8 hooks than on purse seines, gillnets, traps and seines. We found that various gear characteristics, 9 fish characteristics and context variables affect external injuries and mortality. Although the 10 influence of gear characteristics on injuries and mortality can by nature not be compared across 11 gear types, synthesis of the articles reviewed shows that fish characteristics and context variables influence injuries and mortality across gear types. In terms of fish characteristics, decreasing fish length and certain fish species were associated with higher mortality. In terms of context variables, greater capture depth and a longer fishing duration were associated with more injuries and higher mortality, whereas a large change in water temperature, a longer duration of air exposure and a high density in the net were associated with higher mortality. These relations provide options to reduce injuries and mortality from commercial capture fisheries. Implementation of such options, however, would require analysis of potential tradeoffs between welfare benefits, and ecological and economic consequences. 


\section{Introduction}

Concerns about the welfare of production animals have extended from farm animals to fish in aquaculture and capture fisheries (Diggles et al., 2011; Huntingford et al., 2006; OIE, 2016). Huntingford et al. (2006) reviewed the scientific literature on fish welfare and identified welfare issues that arise in aquaculture, recreational fisheries and ornamental fish keeping, but they did not identify the welfare issues that arise in capture fisheries other than pointing out that "there is very little information on the welfare of fish in the context of commercial fisheries" (Huntingford et al., 2006: 362).

This limited information on fish welfare in commercial capture fisheries is likely due to three causes. First, the experience of pain in fish is debated (for insightful but contrasting reviews on this topic, please see Huntingford et al. (2006) and Rose et al. (2014) or special issues on this topic in the journals Diseases of Aquatic Organisms (2007, volume 72, issue 2) and Animal Sentience (2016, no. 3)). Despite the debate whether or not fish can feel pain, fish welfare is increasingly acknowledged to be an important societal issue (Arlinghaus et al., 2007; Braithwaite and Boulcott, 2008; Branson, 2008; OIE, 2016).

Second, information on fish welfare in capture fisheries might be limited because, contrary to fish in aquaculture, the welfare of fish in capture fisheries is directly affected by humans only during the fishes' final life stage. In capture fisheries, various fishing gear types are used, such as trawls, purse seines and traps. Each of these gear types has its own modus operandi, for example in terms of the depths at which the gear type is deployed and the species that it targets. Consequently, the impact on fish welfare differs among gear types; e.g. compare a fish being caught by hook and line with a fish being caught by a trawl net (Metcalfe, 2009). Hence, an investigation into the impact of the capture process on fish welfare should acknowledge these differences in gear types.

Third, information on fish welfare in capture fisheries might be limited because of a (perceived) lack of economically viable, welfare-friendly alternatives to current practices (Jennings et al., 2016). However, by considering the effects of the capture process on fish welfare, improvement options and research gaps pertaining to fish welfare can be identified. Such improvement options may also benefit fishers, e.g., when a change in current practices results in improved societal and consumer acceptance or in less external damages of the captured fish, which increases product quality (Rotabakk et al., 2011; Savina et al., 2016).

Although animal welfare can be defined in various ways (Broom, 2011; Hagen et al., 2011; Korte et al., 2007; Ohl and van der Staay, 2012), key to all definitions is that poor welfare is associated with exceeding the coping capacity of animals, which may result in chronic stressrelated physiology and behaviour, pathology and increased mortality. Fish welfare can focus on the measurable, objective condition of the fish (function-based), on the subjective experience of the fish (feelings-based), and on whether the fish can lead a natural life (nature-based) (Fraser, 2008; Fraser et al., 1997). For the purpose of this study, we selected indicators for fish welfare that are relatively easy measured in both field and laboratory settings: external injuries and mortality. External injuries are the visible effects of the capture process on the fish and mortality is the ultimate consequence resulting from the capture process exceeding the fish's coping capacity. Incidences of injuries or mortality thus indicate that welfare issues occurred during the capture process, which can be the result of a combination of various gear characteristics, fish characteristics and context variables.

The objective of this study was to conduct a review to determine what is known about the effects of the capture process in capture fisheries on fish welfare. This review focuses on external injuries and mortality in teleost (ray-finned) fish species caught in commercial fisheries. Results from this review are derived from and relevant for both discarded fish and landed fish. Although every fish species has its own species-specific characteristics, external injuries and mortality can be assessed across species. 


\section{Methods}

This review on fish welfare in capture fisheries started with the development of a search strategy that was subsequently applied to the literature. Next, the information that was extracted from each relevant article in the literature search was synthesized in relation to this review's objective (Brunton et al., 2012; European Food Safety Authority, 2010).

\subsection{Development and application of a search strategy}

The first step in developing a search strategy for this review was to determine relevant search terms based on key concepts in the research objective, i.e., capture fisheries and fish welfare. Potential search terms relating to capture fisheries were based on the different gear types used in capture fisheries (Nédélec and Prado, 1990). Since not all these gear types are used in the commercial capture of teleost fish, only trawl nets, hook and line (hereafter referred to as hooks), surrounding nets (hereafter referred to as purse seines), gillnets and entangling nets (hereafter referred to as gillnets), traps, and seine nets were included (see Appendix A for a description of these gear types and their main subtypes). Potential search terms relating to fish welfare were identified based on two earlier reviews on fish welfare (Ashley, 2007; Huntingford et al., 2006). The efficacy of each potential search term was determined by comparing results based on all search terms with results based on all search terms except one. In case the exclusion of a search term resulted in the exclusion of a relevant article, the search term was retained because this meant that the search term resulted in an additionally relevant result. Searches to determine search terms were performed in October 2015, and the resulting search terms are shown in Appendix B.

Next, exclusion criteria were defined that were used to determine relevant exclusion terms. These exclusion criteria were based on the objective of this review and subsequent delineations. An article was excluded when it did not focus on teleost fish, capture fisheries, fish welfare, relevant gear types, external injuries or mortality, or when it lacked empirical or experimental data. Such exclusion criteria could not be used directly to exclude irrelevant articles, but rather, were used to define specific exclusion terms. The efficacy of each exclusion term was assessed by adding the exclusion term to the confirmed search terms and determining whether this exclusion term excluded (relevant) results or not. In case relevant or zero results were excluded, an exclusion term was not retained. In addition to these specific exclusion terms, additional exclusion terms were defined to ensure that only peer-reviewed scientific articles and reviews (thus excluding e.g. conference proceedings) in English would be included. Searches to determine exclusion terms were performed in October and November 2015, and the resulting exclusion terms are shown in Appendix B.

Finally, a search with all final search and exclusion terms was performed on 7 January 2016 and resulted in 677 articles. This search was repeated right before article submission (30 June 2017), which resulted in 73 additional articles. The titles, abstracts and full text of the 750 articles were screened using the aforementioned exclusion criteria (Brunton et al., 2012), which resulted in a final list of 85 peer-reviewed scientific articles.

\subsection{Synthesizing information}

For each article, basic information on data collection, species, capture process and capture site was recorded in Excel. Moreover, relevant empirical results, experimental results, results from data analysis, conclusions, limitations and generalizability were recorded for each article. The synthesis of this information focused on the influence of explanatory variables on injuries and mortality.

Since terminology for external injuries was not used consistently across the articles reviewed, these injuries were classified into five broad categories, i.e., scale, skin, fin, pressure and hooking injuries. Scale injuries are injuries such as scale damage and scale loss, skin injuries are injuries such as cuts and tissue loss, fin injuries are injuries such as fin erosion and 
fin loss, pressure injuries are injuries that arise from large changes in depth and pressure such as stomach eversion and exophthalmia (i.e., bulging eyes), and hooking injuries are injuries from hooks specified by their location, i.e., hooking in the mouth, deep-hooking (hook is swallowed) and foul hooking (hooking outside the mouth).

Variables that were commonly used to explain injuries and mortality in the articles reviewed were classified into gear characteristics, fish characteristics and context variables. Gear characteristics that were considered are gear subtype, size and material, and selectivity device. Fish characteristics that were considered are fish length and species. Context variables that were considered are change in water temperature (due to higher temperatures of surface water), capture depth, fishing duration (from setting out to surfacing the gear), duration of air exposure after surfacing, density in the net, species composition in the net and boarding procedure.

Relations between explanatory variables, and injuries and mortality are presented in the Results and Discussion Section if findings on such relations were reported in the articles reviewed.

\section{6}

137

138

139

140

141

142

143

144

145

146

147

148

149

150

151

152

153

154

155

156

157

158

159

160

161

162

163

164

165

166

167

168

\section{Results and discussion}

In total, 85 relevant articles were identified that focused on the welfare of approximately 150 fish species, with cod, herring and sablefish among the main species (see Appendix $C$ for a complete overview including scientific names). Eight of these articles included results on injuries, 51 articles included results on mortality and 26 included results on injuries and mortality.

Table 1 shows that the number of articles on fish welfare in capture fisheries has increased over time and that fish welfare in the northeast Atlantic, the world's third most important fishing area in terms of volumes landed (FAO, 2014), received most research interest. Only eight articles investigated fish welfare in the four other most important fishing areas i.e., the northwest, western central and southeast Pacific, and the eastern Indian Ocean. No studies on fish welfare were found in other fishing areas, such as the eastern central and southwest Atlantic.

In terms of gear types used, Table 1 shows that trawls and hooks received most research interest, whereas purse seines, gillnets, traps and seines received considerably less research interest. Hence, there is less knowledge on the impact of purse seines, gillnets, traps and seines on fish welfare while with these gear types a substantial amount ( 45\%) of fish is caught worldwide (Watson et al., 2006).

\subsection{Injuries}

The occurrence of scale, skin, fin and pressure injuries differs among gear types. Scale, skin and fin injuries are mainly caused by contact with the net (Davis and Ottmar, 2006; Gregory, 1998), with other fish (Davis and Ottmar, 2006) and with species with hard body parts such as crustaceans (Bottari et al., 2003; Suuronen and Erickson, 2010). Hence, such injuries occur more frequently in trawls, purse seines, gillnets and seines than in hooks (Gregory, 1998). Hooks, however, inevitably result in hooking injuries. Pressure injuries commonly occur in fish caught at depths of 25-30 m or more (Gregory, 1998; Humborstad and Mangor-Jensen, 2013), which means that all gear types (unless operated near the surface such as, for example, drifting gillnets or small purse seines) can result in pressure injuries.

The occurrence of injuries not only differs among gear types, but also within gear types due to gear characteristics, fish characteristics and context variables. Table 2 shows that the majority of relations between these explanatory variables and injuries was identified for trawls and hooks, which is in line with the larger number of articles on these gear types included in this review. An example of such a relation that helps in interpreting Table 2 is the relation 
between fish length and injuries when using trawls. Fish length was found to influence injuries positively (i.e., larger fish sustained more injuries) for some but not for all species studied.

Sections 3.1.1 - 3.1.3 discuss only those relations between injuries and explanatory

172

173

174

175

176

177

178

179

180

181

182

183

184

185

186

187

188

189

190

191

192

193

194

195

196

197

198

199

200

201

202

203

204

205

206

207

208

209

210

211

212

213

214

215

216 variables from Table 2 that were identified for a given injury category across multiple gear types or for a single gear type if multiple articles were available. Appendix D provides the references for all relations in Table 2.

\subsubsection{Influence of gear characteristics on injuries}

Table 2 shows that an influence of gear characteristics on injuries was only identified in trawls and hooks. Of these two gear types, a clear relation was only identified for hooks.

In hooks, circle hooks commonly result in less deep-hooking (Kerstetter and Graves, 2006a; Mapleston et al., 2008) and more hooking in the mouth (Falterman and Graves, 2002; Orsi et al., 1993) than J-style hooks, in line with circle hooks' purpose. Cooke and Suski (2004) found that variables such as mouth morphology and hook size have an influence on deephooking in circle and J-style hooks. Such variables could explain why the influence of hook type on foul hooking differs in the literature reviewed, with more foul hooking on J-style hooks in chinook salmon (Orsi et al., 1993), but more foul hooking on circle hooks in white marlin (Kerstetter and Graves, 2006b). No relation between hook type and deep- or foul hooking was identified in other studies (Kerstetter and Graves, 2006a; Mapleston et al., 2008). When circle hooks are offset to increase catch, this may result in more deep-hooking (Rice et al., 2012) and skin injuries (Mapleston et al., 2008), although such relations were only identified in two studies and not even for all species considered in one of these studies (Rice et al., 2012). The influence of hook size on injuries remains unclear since larger hooks were only associated with more skin injuries than smaller hooks in one study and not even for all species included (Mapleston et al., 2008).

\subsubsection{Influence of fish characteristics on injuries}

Table 2 shows that the relation between fish length and injuries remains unclear. For example, larger cod caught by trawl showed more scale and skin injuries than smaller cod caught by trawl (Suuronen et al., 2005), whereas larger cod caught by hook showed less scale injuries than smaller cod caught by hook (Pálsson et al., 2003), while no relation was identified in other studies on cod caught by trawl (Ingólfsson and Jørgensen, 2006; Suuronen et al., 1996b). Identified differences in the relation between fish length and injuries across gear types (Ingólfsson and Jørgensen, 2006; Jones, 1993; Mapleston et al., 2008; Pálsson et al., 2003; Raby et al., 2015; Suuronen et al., 2005, 1996b) could be explained by differences in fish-gear interactions (He, 2010).

The literature reviewed shows that the occurrence of scale, skin, fin and pressure injuries differs between species in trawls and hooks (Depestele et al., 2014; Digre et al., 2010; Pribyl et al., 2011). Such differences between species are likely explained by differences in, for example, morphology and behaviour, and can thus occur in other gear types as well. Therefore, fish species (and fish length) should be included in statistical analyses on catch data to prevent that these fish characteristics become confounding variables.

\subsubsection{Influence of context variables on injuries}

Table 2 shows that greater capture depth and longer fishing duration result in more injuries across multiple gear types, whereas none of the other context variables was studied across gear types in the literature reviewed. Greater capture depth resulted in more skin injuries in several species caught by trawl (Bottari et al., 2003) and hook (Pálsson et al., 2003). In addition, greater capture depth resulted in more pressure injuries in several species caught by trawl (Bottari et al., 2003), hook (Drumhiller et al., 2014; McLennan et al., 2014; Pribyl et al., 2011; Stephen and Harris, 2010) and trap (Rudershausen et al., 2008), although this relation was not identified 
for pearl perch caught by hook (Campbell et al., 2014). Most teleost fish have closed swim 218 bladders that they use for buoyancy, which are inflated and deflated by diffusing gas from the blood. Hence, these fish can adjust to moderate changes in depth and pressure but not to changes as large as those experienced at the end of the capture process when the gear is hauled to the surface. As a result, pressure injuries such as bulging eyes or protrusion of the gut via the mouth or anus occur (Gregory, 1998). In cod, however, overinflation, and therewith pressure injuries, are prevented when internal swim bladder puncture occurs (Humborstad and Mangor-Jensen, 2013), which Humborstad and Mangor-Jensen suggest could also apply to other robust species like cod, but perhaps not to less robust species such as saithe and haddock.

In trawls, longer fishing duration resulted in more skin injuries and additionally in more pressure injuries (Bottari et al., 2003). In traps, longer fishing duration resulted in more fin injuries and for some species also in more scale and skin injuries (Colotelo et al., 2013). Longer fishing duration results in more injuries likely because this explanatory variable aggravates the influence of other explanatory variables on injuries such as density in the net.

\subsection{Mortality}

Mortality of fish caught by trawls, purse seines and seines is higher than mortality of fish caught by gillnets (Benoît et al., 2010), hooks (Benoît et al., 2010; Davis and Olla, 2001) or traps (Rudershausen et al., 2014). This higher mortality for trawls, purse seines, seines and gillnets is likely explained by the higher occurrence of scale, skin and fin injuries in these gear types as compared to hooks and traps, commonly resulting in higher mortality (e.g., Depestele et al., 2014; Olsen et al., 2012; Smith and Scharf, 2011). The higher mortality for trawls, purse seines and seines than for gillnets is additionally explained by the active fishing of these gears as compared to the passive fishing of gillnets. Movement and turbulence of a trawl can cause the codend to twist, adding to the compression that the fish already experience due to the density in the codend (Gregory, 1998).

As for injuries, the occurrence of mortality not only differs among gear types, but also within gear types due to gear characteristics, fish characteristics and context variables. Table 3 shows that the majority of relations between these explanatory variables and mortality was identified in trawls and hooks, though a relatively large number of relations was also identified in the other gear types except seines.

Sections 3.2.1 - 3.2.3 discuss only those relations between mortality and explanatory variables from Table 3 that were identified across multiple gear types or for a single gear type if multiple articles were available. Appendix D provides the references for all relations in Table 3.

\subsubsection{Influence of gear characteristics on mortality}

In trawls, hooks and gillnets, gear subtype was found to affect mortality, although only for hooks a clear relation was identified across articles. In hooks, mortality was higher on J-style hooks than on circle hooks (Falterman and Graves, 2002; Kerstetter and Graves, 2006b, 2008; Orsi et al., 1993) because of more frequent deep-hooking, which results in higher mortality than hooking in the mouth (Campbell et al., 2014; McLennan et al., 2014).

Selectivity devices used in trawls and purse seines sometimes reduce mortality. In trawls, mortality is higher after escape via codend meshes than after escape via sorting grid (Suuronen et al., 1996c), in line with the sorting grid's purpose of reducing escapee mortality. Within codend meshes, mortality was higher after escape from smaller rather than larger meshes (Düzbastilar et al., 2016) and after escape via diamond meshes rather than square meshes (Düzbastilar et al., 2010a, 2015, 2016), in line with square meshes’ purpose of reducing escapee mortality. In purse seining, the influence of selectivity device on mortality was variable, with higher mortality among mackerel that escaped via a sorting grid than for controls, but with no such difference in mortality for saithe (Misund and Beltestad, 2000). In several studies on trawls 
and purse seines, however, there was no relation between selectivity devices and mortality (Düzbastilar et al., 2010b, 2016; Ingólfsson et al., 2007; Suuronen et al., 1996a, 2005).

\subsubsection{Influence of fish characteristics on mortality}

Table 3 shows that fish length and species influence mortality. In general, mortality is higher among smaller than among larger fish in all gear types, i.e., trawls (Depestele et al., 2014; Düzbastilar et al., 2010a, 2010b, 2015, 2016; Hyvärinen et al., 2008; Ingólfsson et al., 2007; Richards et al., 1995; Suuronen et al., 1996a, 1996c; Uhlmann et al., 2016), hooks (Milliken et al., 1999; Pálsson et al., 2003; Stephen and Harris, 2010), purse seines (Marçalo et al., 2010; Tenningen et al., 2012), gillnets (Broadhurst et al., 2009; Purbayanto et al., 2001; Smith and Scharf, 2011), traps (Stewart, 2008) and seines (Broadhurst et al., 2008). The higher mortality among smaller fish could be explained by their poorer swimming ability and endurance as compared to larger fish (Suuronen and Erickson, 2010), which disables them to avoid contact with the trawl, purse seine or seine net (Olla et al., 1997). In gillnets, differences in captured condition between smaller and larger fish could explain differences in mortality since smaller fish are more likely to be gilled (Purbayanto et al., 2001), whereas larger fish are more likely to be pocketed (Purbayanto et al., 2001). The reason for the higher mortality of smaller rather than larger fish caught by hooks, however, remains unclear. In traps, the reverse was also found, i.e., mortality was higher among larger than among smaller herring (Lundin et al., 2012), but the study of Lundin et al. focused on escaped herring, where larger fish likely sustain more severe injuries during their escape than smaller fish. No relation between fish length and mortality was identified for several species in almost all gear types (Bettoli and Scholten, 2006; Broadhurst et al., 2008, 2009; Candy et al., 1996; Düzbastilar et al., 2010a; Kerstetter and Graves, 2006a; McLennan et al., 2014; Stachura et al., 2012; Stephen and Harris, 2010; Suuronen et al., 2005), possibly due to differences between species in e.g. endurance.

An influence of fish species on mortality was reported for each gear type except purse seines (Broadhurst et al., 2008, 2009; Davis, 2007; Digre et al., 2010; Falterman and Graves, 2002; Gisbert and López, 2008; Jurvelius et al., 2000; Morfin et al., 2017; Olla et al., 1997; Santos et al., 2017). Such differences are likely explained by differences between species in, for example, morphology and endurance. In addition, differences in mortality between species are partly explained by the negative relation between fish length and mortality, since species with higher mortality are generally smaller (Broadhurst et al., 2008; Davis, 2007; Digre et al., 2010; Gisbert and López, 2008; Jurvelius et al., 2000).

\subsubsection{Influence of context variables on mortality}

Table 3 shows that the context variables change in water temperature, capture depth, fishing duration, duration of air exposure and density in the net affect mortality across several gear types. A larger change in water temperature due to higher temperatures of surface water resulted in higher mortality of fish caught by trawl (Davis and Olla, 2001; Davis et al., 2001; Hyvärinen et al., 2008; Olla et al., 1998; Suuronen et al., 2005; Uhlmann et al., 2016; Van Beek et al., 1990), hook (Davis and Olla, 2001; Davis et al., 2001; Düzbastilar et al., 2016; Milliken et al., 2009), purse seine (Marçalo et al., 2008, 2010), gillnet (Bettoli and Scholten, 2006; Broadhurst et al., 2009) and trap (MacMillan and Roth, 2012). A larger change in water temperature can expose fish to thermoclines, i.e., changes in water temperature that exceed fish' tolerance limits (Olla et al., 1998). In some studies, however, no relation between water temperature and mortality was identified (Broadhurst et al., 2009; Dieterman et al., 2000; Jurvelius et al., 2000; Turunen et al., 1994), possibly because the change in temperature these fish were exposed to fell within their tolerance limits.

Greater capture depth resulted in higher mortality of fish caught by trawl (Depestele et al., 2014; Ingólfsson et al., 2007; Jurvelius et al., 2000; Richards et al., 1995), hook (Drumhiller et al., 2014; Milliken et al., 2009; Pálsson et al., 2003; Stachura et al., 2012; Wilson Jr and Burns, 
1996), gillnet (Basaran and Samsun, 2004) and trap (MacMillan and Roth, 2012; Rudershausen et al., 2008; Stewart, 2008), although not for pink snapper caught by hook in one study (McLennan et al., 2014). Greater capture depth often results in more pressure injuries (e.g., Bottari et al., 2003; McLennan et al., 2014; Rudershausen et al., 2008), a common cause of mortality (Campbell et al., 2014).

Longer fishing duration resulted in higher mortality of several species caught by trawl (Barkley and Cadrin, 2012; Davis, 2007; Uhlmann et al., 2016; Van Beek et al., 1990), hook (Kerstetter and Graves, 2006a), purse seine (Candy et al., 1996; Digre et al., 2016; Lockwood et al., 1983; Marçalo et al., 2010; Tenningen et al., 2012) and gillnet (Bettoli and Scholten, 2006; Buchanan et al., 2002), although not for several other species caught by trawl (Hyvärinen et al., 2008; Jurvelius et al., 2000). Fishing duration likely aggravates the influence of other variables such as gear (sub)type and density in the net on injuries and mortality. For example, mortality of mackerel as a result of fish density in a purse seine increased with fishing duration (Lockwood et al., 1983).

Longer duration of air exposure resulted in higher mortality of several (but not all; Morfin et al., 2017) species caught by trawl (Barkley and Cadrin, 2012; Davis, 2007; Jones, 1993; Morfin et al., 2017; Richards et al., 1995) and trap (Gisbert and López, 2008), though deck time (which involves air exposure) did not explain mortality of black sea bass (Rudershausen et al., 2008). Longer duration of air exposure increases the chance that asphyxiation occurs and results in mortality. The exact time after which asphyxiation occurs differs between fish (Lambooij et al., 2012; Olsen et al., 2013). In addition, asphyxiation occurs earlier when fish are exposed to air temperatures above their body temperature and later when fish are exposed to air temperatures below their body temperature (Davis and Schreck, 2005; Kestin et al., 1991).

Higher density in the net resulted in higher mortality of several species caught by trawl (Depestele et al., 2014; Richards et al., 1995; Suuronen et al., 2005), purse seine (Digre et al., 2016; Huse and Vold, 2010; Lockwood et al., 1983; Marçalo et al., 2010; Tenningen et al., 2012) and trap (Rudershausen et al., 2008), though not for all species (Candy et al., 1996; Stewart, 2008; Suuronen et al., 1996a). Higher density in the net could also explain the higher mortality of herring and South American pilchard after purse seining and net burst (Misund and Beltestad, 1995) or slipping (Mitchell et al., 2002) rather than after purse seining alone, due to the high density in the net prior to net burst or slipping. Mortality from higher density in the net is likely explained by asphyxiation. High density in the net causes compression that can disable fish to move their gills to breathe, causing them to asphyxiate (Gregory, 1998).

\section{Conclusions and recommendations}

This review has shown that research interest in fish welfare in capture fisheries has increased over time and that research on this topic has focused more on trawls and hooks than on purse seines, gillnets, traps and seines. A comparison across gear types shows that scale, skin and fin injuries occur more frequently in trawls, purse seines, gillnets, traps and seines than in hooks, whereas hooking injuries occur in hooks only. Pressure injuries occur in all gear types included in this review, though their occurrence depends on the depth at which gear types are deployed. Mortality is generally higher in trawls, purse seines and seines than in gillnets, hooks and traps. The choice for gear type based on concerns for fish welfare, however, involves a trade-off between injury types, injury levels, mortality levels, and ecological and economic consequences such as by-catch rates and fuel costs. Still, there are improvement options available within gear types, such as using circle hooks rather than J-style hooks to reduce deep-hooking and resulting mortality.

Although a general conclusion on gear characteristics is by nature not possible, fish characteristics and context variables were found to influence injuries and mortality from capture fisheries across gear types. A decreasing fish length and certain fish species were associated 
with higher mortality. Hence, continued size and species selectivity contributes to improving fish welfare from capture fisheries. A longer fishing duration and a greater capture depth were associated with more external injuries and higher mortality. Such injuries and mortality could be reduced by reducing fishing duration or by bringing gear to the surface more slowly to ensure a more gradual change in depth and pressure, though the ideal surfacing speed (at which fish are retained in the gear but sustain less pressure injuries) is not known. Injuries and mortality could also be reduced by reducing capture depth, although most fish species are only found at specific depths. A large change in water temperature, a longer duration of air exposure and a high density in the net were associated with higher mortality. Catching fish at lower surface water temperatures could thus be one way to reduce mortality, although variations in surface water temperature are likely limited within a fishing season. Mortality could also be reduced by decreasing duration of air exposure (e.g., by pumping fish from the gear and boarding fish in water tanks rather than in air on deck) and by decreasing density in the net (for example by reducing catch weight), though these and other improvement options might have economic consequences (e.g., catch reduction, cost increase, quality improvement) that would require further analysis.

This review focused on injuries and mortality as indicators for fish welfare to provide a first overview of the effects of the capture process on fish welfare. A relatively low number of articles reviewed focused on the different injury categories. As a result, more research is needed on the relationship between external (and internal) injuries, and virtually all explanatory variables included in this review, except capture depth and fishing duration. Moreover, more research is needed on the relation between mortality and most gear characteristics, species composition in the net and various landing procedures to determine their influence on mortality. In addition to the variables considered in this review, research is needed to determine the influence of other variables, such as fish' reproductive cycle, fish morphology, changes in salinity (Broadhurst et al., 2009), light intensity (i.e., visibility) and towing speeds (Olla et al., 1997) on injuries and mortality. This review could be supplemented by findings from recreational fisheries for hooks, stress-related indicators, reflex impairment and (capture-based) aquaculture. Given that capture fisheries precede capture-based aquaculture, this review also provides relevant insights for capture-based aquaculture, where initial condition and survival are crucial for later success.

\section{Acknowledgements}

This research is supported by the project 'WhiteFish', a researchproject to the benefit of small and medium enterprise associationsthat is funded by the European Commission (286141) under theSeventh Framework Program (FP7).The authors would like to thank Leo Nagelkerke for providing valuable feedback on this manuscript. 
Arlinghaus, R., Cooke, S.J., Schwab, A., Cowx, I.G., 2007. Fish welfare: A challenge to the feelings-based approach, with implications for recreational fishing. Fish and Fisheries 8 (1), 57-71.

Ashley, P.J., 2007. Fish welfare: Current issues in aquaculture. Applied Animal Behaviour Science 104 (3-4), 199235.

Barkley, A.S., Cadrin, S.X., 2012. Discard mortality estimation of yellowtail flounder using reflex action mortality predictors. Transactions of the American Fisheries Society 141 (3), 638-644.

Basaran, F., Samsun, N., 2004. Survival rates of black sea turbot (Psetta maxima maeotica, L. 1758) broodstock captured by gill nets from different depths and their adaptation culture conditions. Aquaculture International 12 (3), 321-331.

Benoît, H.P., Hurlbut, T., Chassé, J., 2010. Assessing the factors influencing discard mortality of demersal fishes using a semi-quantitative indicator of survival potential. Fisheries Research 106 (3), 436-447.

Bettoli, P.W., Scholten, G.D., 2006. Bycatch rates and initial mortality of paddlefish in a commercial gillnet fishery. Fisheries Research 77 (3), 343-347.

Bottari, T., Greco, S., Panebianco, A., 2003. Trawling lesions: Incidence in some fish species and preliminary statistical evaluations. Veterinary Research Communications 27 (SUPPL. 1), 285-288.

Braithwaite, V.A., Boulcott, P., 2008. Can fish suffer? In: Branson, E.J. (ed.) Fish welfare, Oxford: Blackwell Publishing, 78-92.

Branson, E. J., 2008. Fish welfare, Oxford: Blackwell Publishing.

Broadhurst, M.K., Millar, R.B., Brand, C. P., 2009. Mitigating discard mortality from dusky flathead platycephalus fuscus gillnets. Diseases of Aquatic Organisms 85 (2), 157-166.

Broadhurst, M.K., Millar, R.B., Brand, C.P., Uhlmann, S.S., 2008. Mortality of discards from southeastern Australian beach seines and gillnets. Diseases of Aquatic Organisms 80 (1), 51-61.

Broom, D.M., 2011. A history of animal welfare science. Acta Biotheoretica 59 (2), 121-137.

Brunton, G., Stansfield, C., Thomas, J., 2012. Finding relevant studies. In: Gough, D., Oliver, S., Thomas, J., (eds.) An introduction to systematic reviews, London: Sage Publications, 107-134.

Buchanan, S., Farrell, A.P., Fraser, J., Gallaugher, P., Joy, R., Routledge, R., 2002. Reducing gill-net mortality of incidentally caught coho salmon. North American Journal of Fisheries Management 22 (4), 1270-1275.

Campbell, M.J., McLennan, M.F., Sumpton, W.D., 2014. Short-term survival of discarded pearl perch (Glaucosoma scapulare Ramsay, 1881) caught by hook-and-line in Queensland, Australia. Fisheries Research 151, 206-212.

Candy, J.R., Carter, E.W., Quinn, T.P., Riddell, B.E., 1996. Adult chinook salmon behavior and survival after catch and release from purse-seine vessels in Johnstone Strait, British Columbia. North American Journal of Fisheries Management 16 (3), 521-529.

Colotelo, A.H., Cooke, S.J., Blouin-Demers, G., Murchie, K.J., Haxton, T., Smokorowski, K.E., 2013. Influence of water temperature and net tending frequency on the condition of fish bycatch in a small-scale inland commercial fyke net fishery. Journal for Nature Conservation 21 (4), 217-224.

Cooke, S.J., Suski, C.D., 2004. Are circle hooks an effective tool for conserving marine and freshwater recreational catch-and-release fisheries? Aquatic Conservation: Marine and Freshwater Ecosystems 14 (3), 299-326.

CWP, 2015. Section H: Fishing areas for statistical purposes. In: CWP (ed), Handbook of Fishery Statistical Standards, Rome: FAO.

Davis, M.W., 2007. Simulated fishing experiments for predicting delayed mortality rates using reflex impairment in restrained fish. ICES J ournal of Marine Science 64 (8), 1535-1542.

Davis, M.W., Olla, B.L., 2001. Stress and delayed mortality induced in Pacific halibut by exposure to hooking, net towing, elevated seawater temperature and air: Implications for management of bycatch. North American J ournal of Fisheries Management 21 (4), 725-732.

Davis, M.W., Olla, B.L., Schreck, C.B., 2001. Stress induced by hooking, net towing, elevated sea water temperature and air in sablefish: Lack of concordance between mortality and physiological measures of stress. Journal of Fish Biology 58 (1), 1-15. 
Davis, M.W., Ottmar, M.L., 2006. Wounding and reflex impairment may be predictors for mortality in discarded or escaped fish. Fisheries Research 82 (1-3), 1-6.

Davis, M.W., Schreck, C.B., 2005. Responses by pacific halibut to air exposure: Lack of correspondence among plasma constituents and mortality. Transactions of the American Fisheries Society 134 (4), 991-998.

Depestele, J., Desender, M., Benoît, H.P., Polet, H., Vincx, M., 2014. Short-term survival of discarded target fish and non-target invertebrate species in the "eurocutter" beam trawl fishery of the southern North Sea. Fisheries Research 154, 82-92.

Dieterman, D.J., Baird, M.S., Galat, D.L., 2000. Mortality of paddlefish in hoop nets in the lower Missouri River, Missouri. North American J ournal of Fisheries Management 20 (1), 226-230.

Diggles, B.K., Cooke, S.J., Rose, J.D., Sawynok, W., 2011. Ecology and welfare of aquatic animals in wild capture fisheries. Reviews in Fish Biology and Fisheries 21 (4), 739-765.

Digre, H., Hansen, U.J., Erikson, U., 2010. Effect of trawling with traditional and 'T90' trawl codends on fish size and on different quality parameters of cod Gadus morhua and haddock Melanogrammus aeglefinus. Fisheries Science 76 (4), 549-559.

Digre, H., Tveit, G.M., Solvang-Garten, T., Eilertsen, A., Aursand, I.G., 2016. Pumping of mackerel (Scomber scombrus) onboard purse seiners, the effect on mortality, catch damage and fillet quality. Fisheries Research 176 (65-75).

Drumhiller, K.L., Johnson, M.W., Diamond, S.L., Reese Robillard, M.M., Stunz, G.W., 2014. Venting or rapid recompression increase survival and improve recovery of red snapper with barotrauma. Marine and Coastal Fisheries 6 (1), 190-199.

Düzbastilar, F.O., Aydin, C., Gül, B., 2016. Mortality of non-target flatfishes escaping from demersal trawl codends. Journal of Applied I chthyology 32 (6),1194-1204.

Düzbastilar, F.O., Laleli, T., Özgül, A., Metin, G., 2015. Determining the severity of skin injuries of red mullet, Mullus barbatus (Actinopterygii: Perciformes: Mullidae), inflicted during escape from trawl codend. Acta Ichthyologica et Piscatoria 45 (1), 75-83.

Düzbastilar, F.O., Özbilgin, H., Aydin, C., Metin, G., Ulaş, A., Lök, A., Metin, C., 2010a. Mortalities of fish escaping from square and diamond mesh codends in the Aegean Sea. Fisheries Research 106 (3), 386-392.

Düzbastilar, F.O., Özgül, A., Aydin, I., Gül, B., Soykan, O., 2010b. A preliminary study on the survival of brown comber, Serranus hepatus (Actinopterygii, Perciformes, Serranidae), escaping from the codend of a bottom trawl. Acta Ichthyologica et Piscatoria 40 (1), 27-36.

European Food Safety Authority, 2010. Application of systematic review methodology to food and feed safety assessments to support decision making. EFSA Journal 8 (6), 1637-1726.

Falterman, B., Graves, J. E., 2002. A preliminary comparison of the relative mortality and hooking efficiency of circle and straight shank ("J") hooks used in the pelagic longline industry. American Fisheries Society Symposium 2002 (30), 80-87.

FAO, 2014. World capture production. Yearbook of Fishery Statistics - Summary tables, accessible via: ftp://ftp.fao.org/FI/STAT/summary/ala.pdf, accessed on: 24 May 2016.

Fraser, D., 2008. Understanding animal welfare: The science in its cultural context, Hoboken: Wiley-Blackwell.

Fraser, D., Weary, D.M., Pajor, E.A., Milligan, B.N., 1997. A scientific conception of animal welfare that reflects ethical concerns. Animal Welfare 6 (3), 187-205.

Gisbert, E., López, M.A., 2008. Impact of glass eel fishery on by-catch fish species: A quantitative assessment. Hydrobiologia 602 (1), 87-98.

Gregory, N. G., 1998. Fish. In Gregory, N.G., (ed.) Animal welfare and meat science, Oxon: CABI Publishing, 195-212.

Hagen, K., van den Bos, R., de Buning, T., 2011. Editorial: Concepts of Animal Welfare. Acta Biotheoretica 59 (2), 93-103.

He, P., 2010. Behavior of Marine Fishes: Capture Processes and Conservation Challenges, Blackwell Publishing Ltd.

Humborstad, O.B., Mangor-J ensen, A., 2013. Buoyancy adjustment after swimbladder puncture in cod Gadus morhua: An experimental study on the effect of rapid decompression in capture-based aquaculture. Marine Biology Research 9 (4), 383-393. 
Huntingford, F.A., Adams, C., Braithwaite, V.A., Kadri, S., Pottinger, T.G., Sandøe, P., Turnbull, J.F., 2006. Current issues in fish welfare. Journal of Fish Biology 68 (2), 332-372.

Huse, I., Vold, A., 2010. Mortality of mackerel (Scomber scombrus L.) after pursing and slipping from a purse seine. Fisheries Research 106 (1), 54-59.

Hyvärinen, P., Leppäniemi, V., Johansson, K., Korhonen, P., Suuronen, P., 2008. Stress and survival of small pike-perch Sander lucioperca (L.) after trawling and chilling. Journal of Fish Biology 72 (10), 2677-2688.

Ingólfsson, O.A., Jørgensen, T., 2006. Escapement of gadoid fish beneath a commercial bottom trawl: Relevance to the overall trawl selectivity. Fisheries Research 79 (3), 303-312.

Ingólfsson, O.A., Soldal, A.V., Huse, I., Breen, M., 2007. Escape mortality of cod, saithe, and haddock in a Barents Sea trawl fishery. ICES J ournal of Marine Science 64 (9), 1836-1844.

Jennings, S., Stentiford, G.D., Leocadio, A.M., Jeffery, K.R., Metcalfe, J.D., Katsiadaki, I., Auchterlonie, N.A., Mangi, S.C., Pinnegar, J.K., Ellis, T., Peeler, E.J., Luisetti, T., Baker-Austin, C., Brown, M., Catchpole, T.L., Clyne, F.J., Dye, S.R., Edmonds, N.J., Hyder, K., Lee, J., Lees, D.N., Morgan, O.C., O'Brien, C.M., Oidtmann, B., Posen, P.E., Santos, A.R., Taylor, N.G.H., Turner, A.D., Townhill, B.L., Verner-J effreys, D.W., 2016. Aquatic food security: insights into challenges and solutions from an analysis of interactions between fisheries, aquaculture, food safety, human health, fish and human welfare, economy and environment. Fish and Fisheries 17 (4), 893-938.

Jones, J.B., 1993. Net damage injuries to New Zealand Hoki, Macruronus novaezelandiae. New Zealand Journal of Marine and Freshwater Research 27, 23-30.

Jurvelius, J., Riikonen, R., Marjomäki, T.J., Lilja, J., 2000. Mortality of pike-perch (Stizostedion lucioperca), brown trout (Salmo trutta) and landlocked salmon (Salmo salar $\mathrm{m}$. sebago) caught as by-catch in pelagic trawling in a Finnish lake. Fisheries Research 45 (3), 291-296.

Kerstetter, D.W., Graves, J.E., 2006a. Effects of circle versus J-style hooks on target and non-target species in a pelagic longline fishery. Fisheries Research 80 (2-3), 239-250.

Kerstetter, D.W., Graves, J.E., 2006b. Survival of white marlin (Tetrapturus albidus) released from commercial pelagic longline gear in the western North Atlantic. Fishery Bulletin 104 (3), 434-444.

Kerstetter, D.W., Graves, J.E., 2008. Postrelease survival of sailfish caught by commercial pelagic longline gear in the southern Gulf of Mexico. North American Journal of Fisheries Management 28 (5), 1578-1586.

Kestin, S.C., Wotton, S.B., Gregory, N.G., 1991. Effect of slaughter by removal from water on visual evoked activity in the brain and reflex movement of rainbow trout (Oncorhynchus mykiss). Veterinary Record 128 (19), 443-446.

Korte, S.M., Olivier, B., Koolhaas, J.M., 2007. A new animal welfare concept based on allostasis. Physiology and Behavior 92 (3), 422-428.

Lambooij, E., Digre, H., Reimert, H.G.M., Aursand, I.G., Grimsmo, L., van de Vis, J.W., 2012. Effects of on-board storage and electrical stunning of wild cod (Gadus morhua) and haddock (Melanogrammus aeglefinus) on brain and heart activity. Fisheries Research 127-128, 1-8.

Lockwood, S.J., Pawson, M.G., Eaton, D.R., 1983. The effects of crowding on mackerel (Scomber scombrus L.) Physical condition and mortality. Fisheries Research 2 (2), 129-147.

Lundin, M., Calamnius, L., Lunneryd, S.G., 2012. Survival of juvenile herring (Clupea harengas membras) after passing through a selection grid in a pontoon trap. Fisheries Research 127-128, 83-87.

MacMillan, E., Roth, B., 2012. By-catch in the Saginaw Bay, Lake Huron commercial trap net fishery. Journal of Great Lakes Research 38 (2), 353-361.

Mapleston, A., Welch, D., Begg, G.A., McLennan, M., Mayer, D., Brown, I., 2008. Effect of changes in hook pattern and size on catch rate, hooking location, injury and bleeding for a number of tropical reef fish species. Fisheries Research 91 (2-3), 203-211.

Marçalo, A., Marques, T.A., Araújo, J., Pousão-Ferreira, P., Erzini, K., Stratoudakis, Y., 2010. Fishing simulation experiments for predicting the effects of purse-seine capture on sardine (Sardina pilchardus). ICES J ournal of Marine Science 67 (2), 334-344.

Marçalo, A., Pousão-Ferreira, P., Mateus, L., Duarte Correia, J.H., Stratoudakis, Y., 2008. Sardine early survival, physical condition and stress after introduction to captivity. Journal of Fish Biology 72 (1), 103-120. 
McLennan, M.F., Campbell, M.J., Sumpton, W.D., 2014. Surviving the effects of barotrauma: Assessing treatment options and a 'natural' remedy to enhance the release survival of line caught pink snapper (Pagrus auratus). Fisheries Management and Ecology 21 (4), 330-337.

Metcalfe, J.D., 2009. Welfare in wild-capture marine fisheries. Journal of Fish Biology 75 (10), 2855-2861.

Milliken, H.O., Farrington, M., Arnold Carr, H., Lent, E., 1999. Survival of atlantic cod (Gadus morhua) in the northwest atlantic longline fishery. Marine Technology Society J ournal 33 (2), 19-24.

Milliken, H.O., Farrington, M., Rudolph, T., Sanderson, M., 2009. Survival of discarded sublegal Atlantic cod in the Northwest Atlantic demersal longline fishery. North American Journal of Fisheries Management 29 (4), 985-995.

Misund, O.A., Beltestad, A.K., 1995. Survival of herring after simulated net bursts and conventional storage in net pens. Fisheries Research 22 (3-4), 293-297.

Misund, O.A., Beltestad, A.K., 2000. Survival of mackerel and saithe that escape through sorting grids in purse seines. Fisheries Research 48 (1), 31-41.

Mitchell, R.W., Blight, S.J., Gaughan, D.J., Wright, I.W., 2002. Does the mortality of released Sardinops sagax increase if rolled over the headline of a purse seine net? Fisheries Research 57 (3), 279-285.

Morfin, M., Méhault, S., Benoît, H.P., Kopp, D., 2017. Narrowing down the number of species requiring detailed study as candidates for the EU Common Fisheries Policy discard ban. Marine Policy 77, 23-29.

Nédélec, C., Prado, J., 1990. Definition and classification of fishing gear categories. FAO Fisheries Technical Paper, Rome: FAO.

Ohl, F., van der Staay, F.J., 2012. Animal welfare: At the interface between science and society. Veterinary Journal 192, 13-19.

OIE, 2016. Welfare of farmed fish. In: Aquatic Animal Health Code, accessible via http://www.oie.int/index. php?id=171\&L=0\&htmfile=titre_1.7.htm, accessed on: $31 \mathrm{~J}$ anuary 2018.

Olla, B.L., Davis, M.W., Schreck, C.B., 1997. Effects of simulated trawling on sablefish and walleye pollock: The role of light intensity, net velocity and towing duration. Journal of Fish Biology 50 (6), 1181-1194.

Olla, B.L., Davis, M.W., Schreck, C.B., 1998. Temperature magnified postcapture mortality in adult sablefish after simulated trawling. Journal of Fish Biology 53 (4), 743-751.

Olsen, R.E., Oppedal, F., Tenningen, M., Vold, A., 2012. Physiological response and mortality caused by scale loss in Atlantic herring. Fisheries Research 129-130, 21-27.

Olsen, S.H., Tobiassen, T., Akse, L., Evensen, T.H., Midling, K.T., 2013. Capture induced stress and live storage of Atlantic cod (Gadus morhua) caught by trawl: Consequences for the flesh quality. Fisheries Research $147,446-453$.

Orsi, J.A., Wertheimer, A.C., Jaenicke, H.W., 1993. Influence of selected hook and lure types on catch, size, and mortality of commercially troll-caught chinook salmon. North American J ournal of Fisheries Management $13(4), 709-722$.

Pálsson Ó.K., Einarsson, H.A., Björnsson, H., 2003. Survival experiments of undersized cod in a hand-line fishery at Iceland. Fisheries Research 61 (1-3), 73-86.

Pribyl, A.L., Kent, M.L., Parker, S.J., Schreck, C.B., 2011. The response to forced decompression in six species of pacific rockfish. Transactions of the American Fisheries Society 140 (2), 374-383.

Purbayanto, A., Tsunoda, A., Akiyama, S., Arimoto, T., Tokai, T., 2001. Survival of Japanese whiting Sillago japonica and by-catch species captured by a sweeping trammel net. Fisheries Science 67 (1), 21-29.

Raby, G.D., Hinch, S.G., Patterson, D.A., Hills, J.A., Thompson, L.A., Cooke, S.J., 2015. Mechanisms to explain purse seine bycatch mortality of coho salmon. Ecological Applications 25 (7), 1757-1775.

Rice, P.H., Serafy, J.E., Snodgrass, D., Prince, E.D., 2012. Performance of non-offset and $10^{\circ}$ offset $18 / 0$ circle hooks in the United states pelagic longline fishery. Bulletin of Marine Science 88 (3), 571-587.

Richards, L.J., J eff, J., Schnute, J.T., 1995. Factors influencing bycatch mortality of trawl-caught Pacific halibut. North American Journal of Fisheries Management 15 (2), 266-276.

Rose, J.D., Arlinghaus, R., Cooke, S.J., Diggles, B.K., Sawynok, W., Stevens, E.D., Wynne, C.D.L., 2014. Can fish really feel pain? Fish and Fisheries 15, 97-133. 
Rotabakk, B.T., Skipnes, D., Akse, L., Birkeland, S., 2011. Quality assessment of Atlantic cod (Gadus morhua) caught by longlining and trawling at the same time and location. Fisheries Research 112 (1-2), 44-51.

Rudershausen, P.J., Baker Jr, M.S., Buckel, J.A., 2008. Catch rates and selectivity among three trap types in the U.S. South Atlantic black sea bass commercial trap fishery. North American Journal of Fisheries Management 28 (4), 1099-1107.

Rudershausen, P.J., Buckel, J.A., Hightower, J.E., 2014. Estimating reef fish discard mortality using surface and bottom tagging: Effects of hook injury and barotrauma. Canadian Journal of Fisheries and Aquatic Sciences $71(4), 514-520$.

Santos, M.N., Lino, P.G., Coelho, R., 2017. Effects of leader material on catches of shallow pelagic longline fisheries in the southwest Indian Ocean. Fishery Bulletin 115 (2).

Savina, E., Karlsen, J.D., Frandsen, R.P., Krag, L.A., Kristensen, K., Madsen, N., 2016. Testing the effect of soak time on catch damage in a coastal gillnetter and the consequences on processed fish quality. Food Control $70(1), 310-317$.

Smith, W.E., Scharf, F.S., 2011. Postrelease survival of sublegal southern flounder captured in a commercial gillnet fishery. North American Journal of Fisheries Management 31 (3), 445-454.

Stachura, M.M., Lunsford, C.R., Rodgveller, C.J., Heifetz, J., 2012. Estimation of discard mortality of sablefish (Anoplopoma fimbria) in Alaska longline fisheries. Fishery Bulletin 110 (2), 271-279.

Stephen, J.A., Harris, P.J., 2010. Commercial catch composition with discard and immediate release mortality proportions off the southeastern coast of the United States. Fisheries Research 103 (1-3), 18-24.

Stewart, J., 2008. Capture depth related mortality of discarded snapper (Pagrus auratus) and implications for management. Fisheries Research 90 (1-3), 289-295.

Suuronen, P., Erickson, D.L., 2010. Mortality of animals that escape fishing gears or are discarded after capture: Approaches to reduce mortality. In: He, P. (ed), Behavior of Marine Fishes, Blackwell Publishing Ltd., 265-293.

Suuronen, P., Erickson, D.L., Orrensalo, A., 1996a. Mortality of herring escaping from pelagic trawl codends. Fisheries Research 25 (3-4), 305-321.

Suuronen, P., Lehtonen, E., J ounela, P., 2005. Escape mortality of trawl caught Baltic cod (Gadus morhua) - The effect of water temperature, fish size and codend catch. Fisheries Research 71 (2), 151-163.

Suuronen, P., Lehtonen, E., Tschernij, V., Larsson, P.O., 1996b. Skin injury and mortality of Baltic cod escaping from trawl codends equipped with exit windows. Archive of Fishery and Marine Research 44 (3), 165178.

Suuronen, P., Perez-Comas, J.A., Lehtonen, E., Tschernij, V., 1996c. Size-related mortality of herring (Clupea harengus L.) escaping through a rigid sorting grid and trawl codend meshes. ICES Journal of Marine Science 53 (4), 691-700.

Tenningen, M., Vold, A., Olsen, R.E., 2012. The response of herring to high crowding densities in purse-seines: Survival and stress reaction. ICES J ournal of Marine Science 69 (8), 1523-1531.

Turunen, T., Käkelä, A., Hyvärinen, H., 1994. Trawling stress and mortality in undersized ( $<40 \mathrm{~cm})$ brown trout (Salmo trutta L.). Fisheries Research 19 (1-2), 51-64.

UhImann, S.S., Theunynck, R., Ampe, B., Desender, M., Soetaert, M., Depestele, J., 2016. Injury, reflex impairment, and survival of beam-trawled flatfish. ICES J ournal of Marine Science 73 (4), 1244-1254.

Van Beek, F.A., Van Leeuwen, P.I., Rijnsdorp, A.D., 1990. On the survival of plaice and sole discards in the ottertrawl and beam-trawl fisheries in the North Sea. Netherlands Journal of Sea Research 26 (1), 151-160.

Watson, R., Revenga, C., Kura, Y., 2006. Fishing gear associated with global marine catches. I. Database development. Fisheries Research 79 (1-2), 97-102.

Wilson Jr, R.R., Burns, K.M., 1996. Potential survival of released groupers caught deeper than $40 \mathrm{~m}$ based on shipboard and in-situ observations, and tag-recapture data. Bulletin of Marine Science 58 (1), 234-247. 
754 Table 1: year of publication, capture site and gear type of the 85 articles that were included 755 in the review

\begin{tabular}{|c|c|c|}
\hline \multirow{2}{*}{\multicolumn{2}{|c|}{ Year of publication: }} & \multirow[t]{2}{*}{ Number of articles } \\
\hline & & \\
\hline- & $1980-1989$ & 1 \\
\hline- & 1990-1999 & 15 \\
\hline- & 2000-2009 & 34 \\
\hline- & $2010-2017^{1}$ & 35 \\
\hline \multicolumn{3}{|c|}{ Capture site: } \\
\hline \multicolumn{3}{|c|}{ - Ocean²: } \\
\hline & Northwest Pacific & 2 \\
\hline & Western central Pacific & 3 \\
\hline & Northeast Atlantic & 22 \\
\hline & Eastern Indian Ocean & 1 \\
\hline & Southeast Pacific & 2 \\
\hline & Western Indian Ocean & 1 \\
\hline & Eastern Central Atlantic & - \\
\hline & Northeast Pacific & 6 \\
\hline & Southwest Atlantic & - \\
\hline & Eastern central Pacific & - \\
\hline & Northwest Atlantic & 5 \\
\hline & Southeast Atlantic & - \\
\hline & Western central Atlantic & 7 \\
\hline & Mediterranean and Black Sea & 7 \\
\hline & Southwest Pacific & 2 \\
\hline & Antarctic Atlantic & - \\
\hline & Antarctic Indian Ocean & - \\
\hline & Antarctic Pacific & - \\
\hline & Arctic sea & - \\
\hline & Northwest Atlantic and western central Atlantic & 3 \\
\hline - & Freshwater body (i.e. lake or river) & 12 \\
\hline - & Laboratory study & 10 \\
\hline - & Not reported & 2 \\
\hline \multicolumn{3}{|c|}{ Gear type ${ }^{3}$ : } \\
\hline - & Trawls & 33 \\
\hline - & Hooks & 24 \\
\hline - & Purse seines & 11 \\
\hline- & Gillnets & 9 \\
\hline - & Traps & 9 \\
\hline - & Seines & 2 \\
\hline - & Generally applicable & 4 \\
\hline
\end{tabular}



and context variables ${ }^{2}$ in trawls, hooks, purse seines and traps ${ }^{3}$

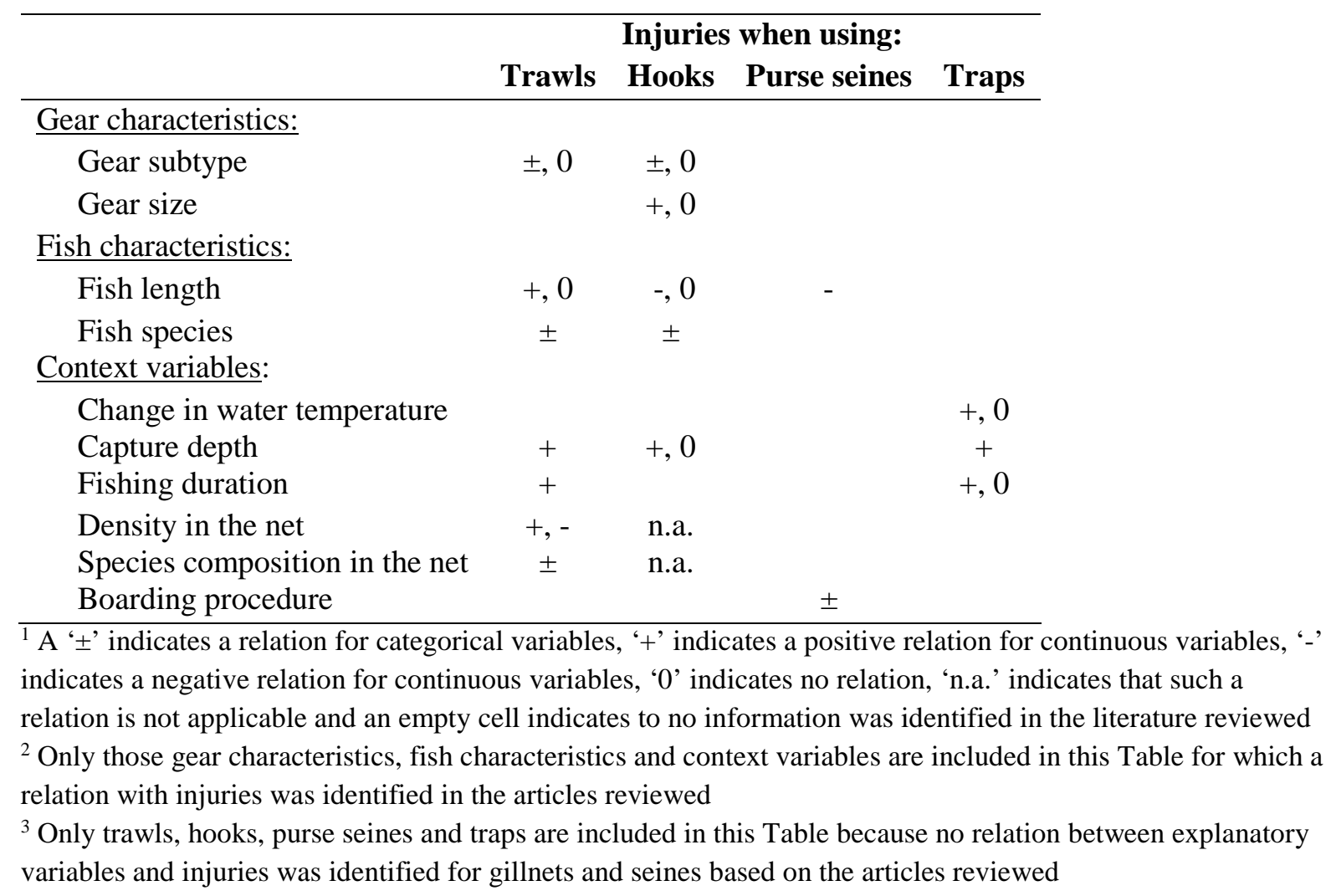




\begin{tabular}{|c|c|c|c|c|c|c|}
\hline & \multicolumn{6}{|c|}{ Mortality when using: } \\
\hline & Trawls & Hooks & Purse seines & Gillnets & Traps & Seines \\
\hline \multicolumn{7}{|l|}{ Gear characteristics: } \\
\hline Gear subtype &, \pm 0 &, \pm 0 & & \pm & & \\
\hline Selectivity device &, \pm 0 & &, \pm 0 & & & \\
\hline Gear material & & \pm & & \pm & & \\
\hline \multicolumn{7}{|l|}{ Fish characteristics: } \\
\hline $\begin{array}{l}\text { Fish length } \\
\text { Fish species }\end{array}$ & $\begin{array}{l}-, 0 \\
\pm\end{array}$ & $\begin{array}{l}-, 0 \\
\pm\end{array}$ &,- 0 & $\begin{array}{l}-, 0 \\
\pm\end{array}$ & $\begin{array}{c}-,+ \\
\pm\end{array}$ & $\begin{array}{l}-, 0 \\
\pm\end{array}$ \\
\hline \multicolumn{7}{|l|}{ Context variables: } \\
\hline Change in water temperature &,+ 0 & + & + &,+ 0 &,+ 0 & \\
\hline Capture depth & + &,+ 0 & & + & + & \\
\hline Fishing duration &,+ 0 & + & + & + & & \\
\hline Duration of air exposure &,+ 0 & & & &,+ 0 & \\
\hline Density in the net &,+ 0 & n.a. &,+ 0 & &,+ 0 & \\
\hline $\begin{array}{l}\text { Species composition in the net } \\
\text { Boarding procedure }\end{array}$ & \pm & $\begin{array}{c}\text { n.a. } \\
\pm\end{array}$ & \pm & & & \\
\hline
\end{tabular}
indicates a negative relation for continuous variables, ' 0 ' indicates no relation, 'n.a.' indicates that such a relation is not applicable and an empty cell indicates to no information was identified in the literature reviewed ${ }^{2}$ Only those gear characteristics, fish characteristics and context variables are included in this Table for which a relation with mortality was identified in the articles reviewed 
Source: Food and Agriculture Organization of the United Nations, (1990), Nédélec and Prado, Definition and classification of fishing gear categories,

782 (http://www.fao.org/docrep/008/t0367t/t0367t00.htm). Reproduced with permission

783

\section{Trawls}

785

Trawls are towed nets that are cone-shaped with a large collection bag at the end (codend). The two main types of trawls are demersal beam trawl (Figure A1) and pelagic or demersal otter trawls (Figure A2), operated individually or in pairs.

788

789

790

791

792

793

794

795

796

797

798

799

800

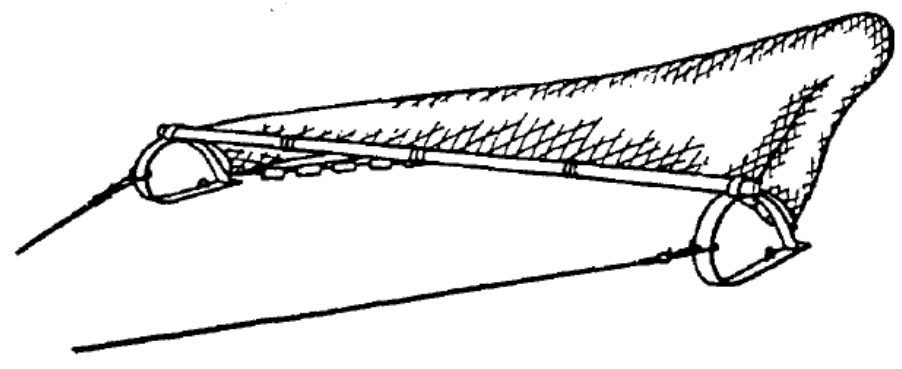

Figure A1: beam trawl

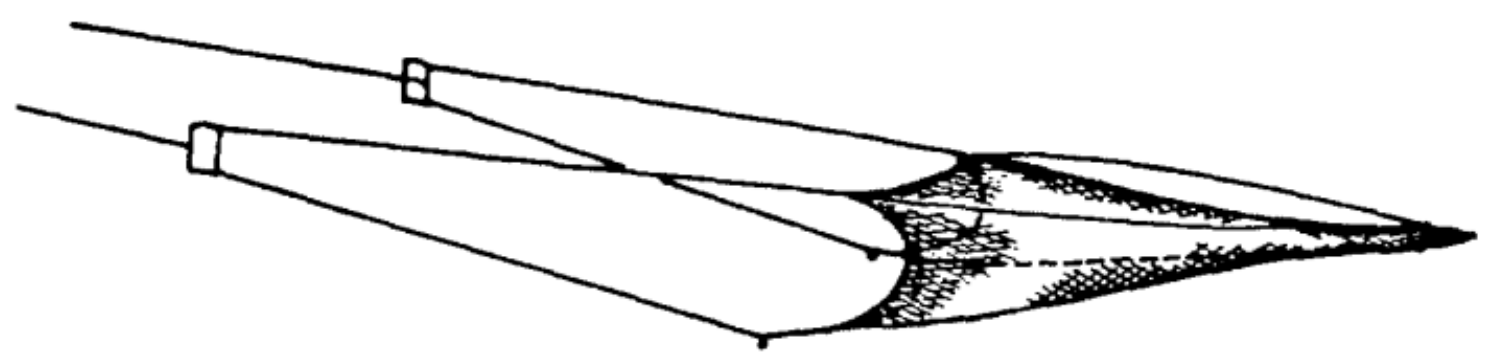

Figure A2: otter trawl

\section{Hooks}

Hooks are baited with artificial or natural bait to attract and capture fish. A hook on a single line (either electronically or manually operated) is called a handline, whereas multiple hooks on single or multiple lines are called (set or drifting) longlines (Figure A3).

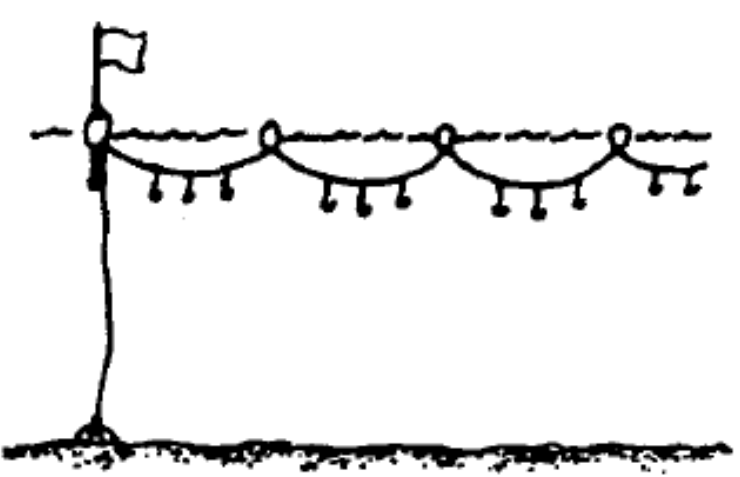

Figure A3: (set) longline 
802 Purse seines surround a school of fish with a wall of netting that is subsequently closed at the 803 bottom and drawn up (pursed) to the surface (Figure A4).

804

805

806

807

808

809

810

811

812

813

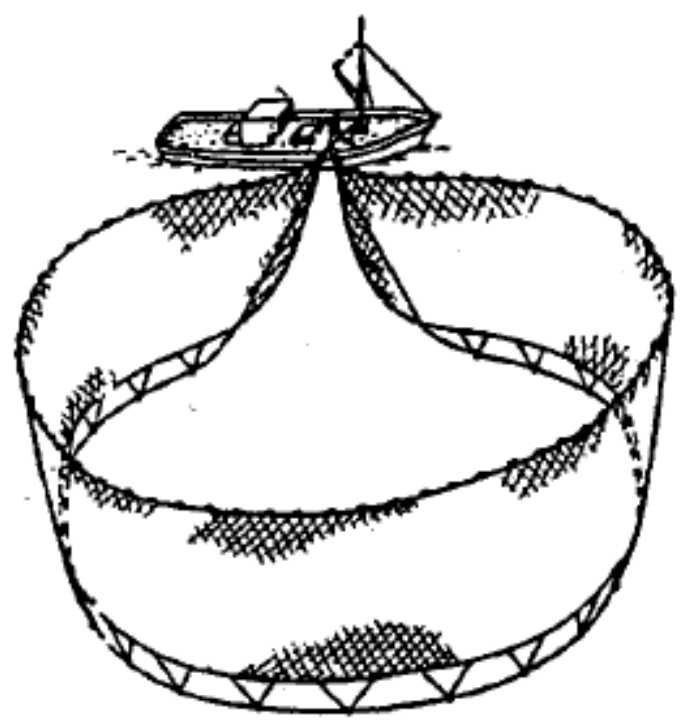

Figure A4: purse seine

\section{Gillnets}

Gillnets (Figure A5) capture fish through snagging (caught by the mouth or head), gilling (caught by the gills), wedging (caught by a larger part of the body) entangling (caught by protruding body parts such as teeth or spines), or pocketing (caught in a pocket of netting, occurs only in trammel nets). These nets can be deployed at the bottom (set gillnets), near the surface (drifting gillnets), on stakes in coastal waters (fixed gillnets) or in multiple rows of nets (trammel nets).

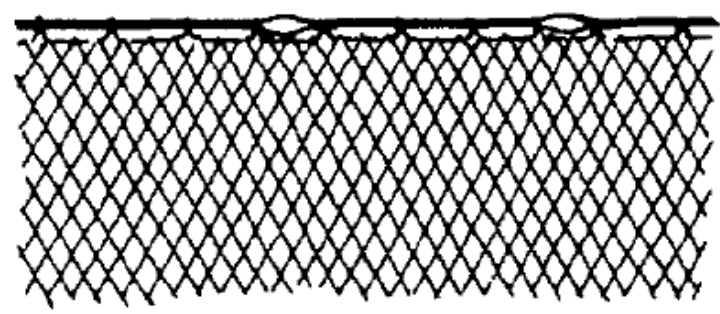

814

815

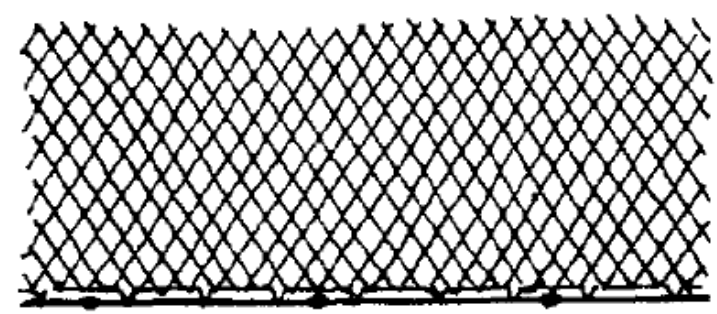

816

Figure A5: gillnet 
818 Traps are a gear type that the fish enter voluntarily but cannot escape. Subtypes of traps are e.g.

819 pots (Figure A6) and fyke nets (Figure A7).

820

821

822

823

824

825

826

827

828

829

830

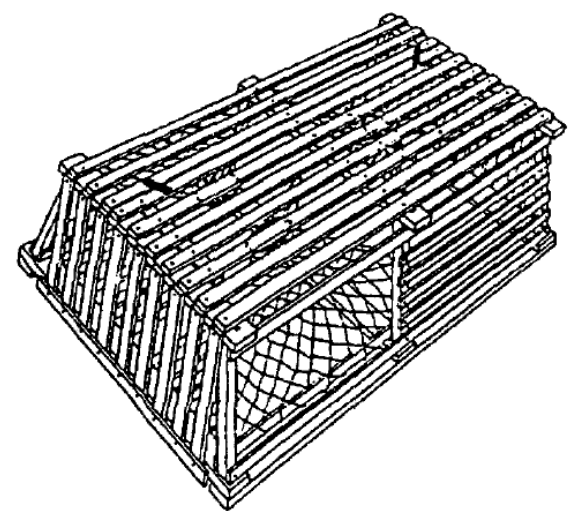

Figure A6: pot

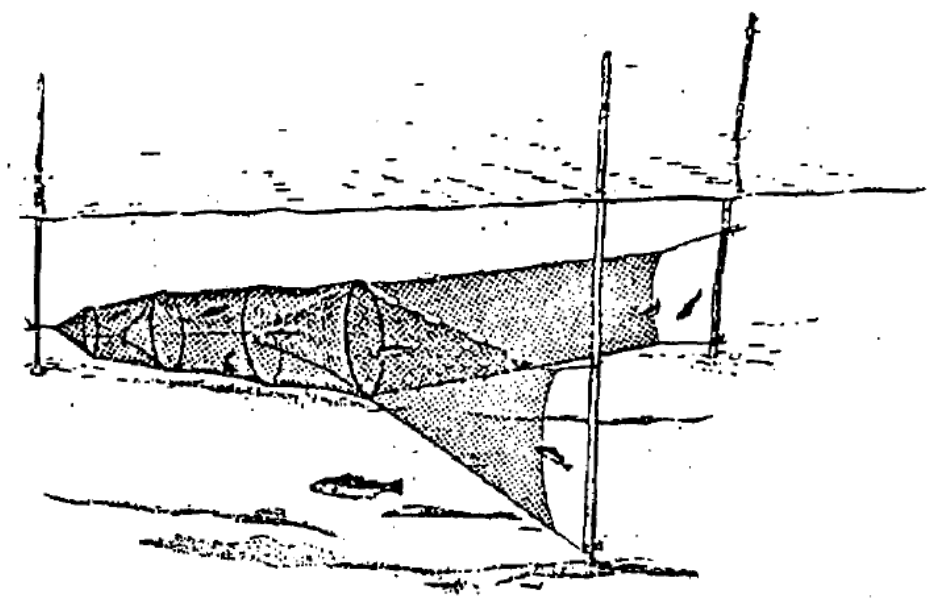

Figure A7: fyke net

\section{Seines}

Seines are towed nets that surround an area of water with a very long net with or without a bag at the centre (Figure A8). Two types of seines are boat seines and beach seines.

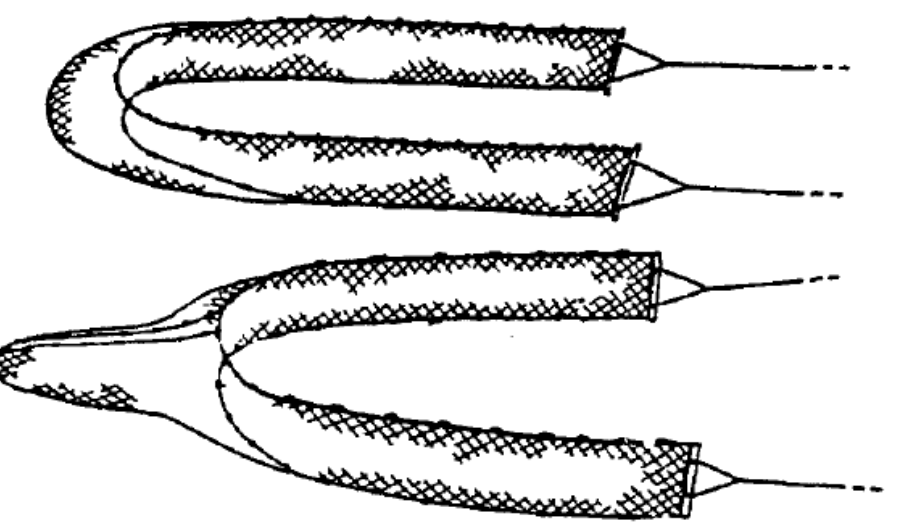

831

832

Figure A8: seine nets 
Final search string:

836 ((((TITLE-ABS-KEY (injur* OR mortality OR exhaust* OR "physical damage" OR "scale 837 loss" OR abrasion OR asphyxia*) AND TITLE-ABS-KEY (fisheries OR fishing OR sein* OR 838 trawl* OR "trammel net") AND NOT TITLE-ABS-KEY (whale OR lobster OR mollusc OR 839 cetacean OR krill OR clam OR urchin OR seal OR seabird OR population OR recruitment OR 840 growth OR exploitation OR "natural mortality" OR oil OR "sea lice" OR worker OR 841 occupation* OR farm* OR patient OR trophic OR virus OR medic* OR viral OR pond OR 842 accident* OR genetic OR infectious OR closure OR nitrogen OR genotype OR "marine 843 protected area" OR octopus OR phenotype OR toxi* OR *economic OR reared OR diet* OR 844 hatching OR shrimp OR decision OR overfish* OR immun* OR feed OR aquarium OR 845 tournament OR rearing OR "risk assessment" OR "ghost fishing" OR hatched OR real-time OR 846 ornamental OR crocodile OR derelict OR "fish aggregating device") AND NOT TITLE (shark 847 OR turtle OR stock OR managing OR fishermen OR fisher OR angl* OR environment OR 848 biology OR disease OR conservation OR "climate change" OR crab OR habitat OR infect* OR 849 ecosystem OR gen* OR seasonal OR bacteria OR benthic OR cage OR clos* OR "sport fishing" 850 OR vulnerable OR egg OR coral OR acid* OR effort OR distribut* OR exposed OR "fisheries 851 management" OR *cultured OR fauna OR hatch* OR quota OR captive OR risk OR tagged) 852 AND NOT KEY (health OR catch-and-release OR shark OR turtle OR fishermen OR fisher 853 OR bacteria OR habitat OR drug OR recreational OR pheno* OR clos* OR benthic OR crab 854 OR suscept* OR egg OR feed* OR quota OR fauna))))) AND (LIMIT-TO (DOCTYPE, "ar") 855 OR LIMIT-TO (DOCTYPE, "re")) AND (LIMIT-TO (LANGUAGE, "English")) 


\section{Appendix C}

\begin{tabular}{|c|c|c|}
\hline Reference & Species & Scientific names \\
\hline Barkley and Cadrin (2012) & Yellowtail flounder & Limanda ferruginea \\
\hline Basaran and Samsun (2004) & Black Sea turbot & Psetta maxima maeotica \\
\hline \multirow[t]{10}{*}{ Benoît et al. (2010) } & American plaice & Hippoglossoides platessoides \\
\hline & Atlantic cod & Gadus morhua \\
\hline & Atlantic halibut & Hippoglossus hippoglossus \\
\hline & Eelpouts & $\begin{array}{l}\text { Lycodes lavalaei, Lycodes vahlii, } \\
\text { Zoarces americanus }\end{array}$ \\
\hline & Greenland cod & Gadus ogac \\
\hline & Sculpins & $\begin{array}{l}\text { Myoxocephalus octodecemspinosus, } \\
\text { Myoxocephalus scorpius, } \\
\text { Hemitripterus americanus }\end{array}$ \\
\hline & White hake & Urophycis tenuis \\
\hline & Winter flounder & Pseudopleuronectes americanus \\
\hline & Witch flounder & Glyptocephalus cynoglossus \\
\hline & Wolffishes & Anarhichas lupus (mainly) \\
\hline Bettoli and Scholten (2006) & Paddlefish & Polyodon spathula \\
\hline \multirow[t]{4}{*}{ Bottari et al. (2003) } & Blue whiting & Micromesisitius poutassou \\
\hline & European hake & Merluccius merluccius \\
\hline & Greater forkbeard & Phycis blennioides \\
\hline & Red mullet & Mullus barbatus \\
\hline \multirow[t]{13}{*}{ Broadhurst et al. (2008) } & Blue salmon catfish & Neoarius graeffei \\
\hline & Castelnau's herring & Herklotsichthys castelnaui \\
\hline & Common silver belly & Gerres subfasciatus \\
\hline & Common toadfish & Tetractenos hamiltoni \\
\hline & Dusky flathead & Platycephalus fuscus \\
\hline & Eastern Sea Garfish & Hyporhamphus australis \\
\hline & Flat-tail mullet & Liza argentea \\
\hline & Flathead grey mullet & Mugil cephalus \\
\hline & Goldlined seabream & Rhabdosargus sarba \\
\hline & Old wife & Enoplosus armatus \\
\hline & Sand whiting & Sillago ciliata \\
\hline & Surf bream & Acanthopagrus australis \\
\hline & Trevallies & Caranx sp. \\
\hline \multirow[t]{10}{*}{ Broadhurst et al. (2009) } & Black sole & Synaptura nigra \\
\hline & Common silver belly & Gerres subfasciatus \\
\hline & Dusky flathead & Platycephalus fuscus \\
\hline & Estuary perch & Macquaria colonorum \\
\hline & Goldlined seabream & Rhabdosargus sarba \\
\hline & Largetooth flounder & Pseudorhombus arsius \\
\hline & Parore & Girella tricuspidata \\
\hline & Sand whiting & Sillago ciliata \\
\hline & Surf bream & Acanthopagrus australis \\
\hline & Yellowfin leather jacket & Meuschenia trachylepis \\
\hline Buchanan et al. (2002) & Coho salmon & Oncorhynchus kisutch \\
\hline Campbell et al. (2014) & Pearl perch & Glaucosoma scapulare \\
\hline Candy et al. (1996) & Chinook salmon & Oncorhynchus tshawytscha \\
\hline \multirow[t]{2}{*}{ Colotelo et al. (2013) } & Bluegill & Lepomis macrochirus \\
\hline & Largemouth bass & Micropterus salmoides \\
\hline
\end{tabular}




\begin{tabular}{|c|c|c|}
\hline Reference & Species & Scientific names \\
\hline & Northern pike & Esox Lucius \\
\hline \multirow[t]{4}{*}{ Davis (2007) } & Coho salmon & Oncorhynchus kisutch \\
\hline & Northern rock sole & Lepidopsetta polyxystra \\
\hline & Pacific halibut & Hippoglossus stenolepis \\
\hline & Walleye pollock & Theragra chalcogramma \\
\hline Davis and Olla (2001) & Pacific halibut & Hippoglossus stenolepis \\
\hline \multirow[t]{4}{*}{ Davis and Ottmar (2006) } & Northern rock sole & Lepidopsetta polyxystra \\
\hline & Pacific halibut & Hippoglossus stenolepis \\
\hline & Sablefish & Anoplopoma fimbria \\
\hline & Walleye pollock & Theragra chalcogramma \\
\hline Davis and Schreck (2005) & Pacific halibut & Hippoglossus stenolepis \\
\hline Davis et al. (2001) & Sablefish & Anoplopoma fimbria \\
\hline \multirow[t]{5}{*}{ Depestele et al. (2014) } & Cod & Gadus morhua \\
\hline & European plaice & Pleuronectes platessa \\
\hline & Poutings & Trisopterus sp. \\
\hline & Sole & Solea solea \\
\hline & Whiting & Merlangius merlangus \\
\hline Dieterman et al. (2000) & Paddlefish & Polyodon spathula \\
\hline \multirow[t]{2}{*}{ Digre et al. (2010) } & Cod & Gadus morhua \\
\hline & Haddock & Melanogrammus aeglefinus \\
\hline (Digre et al. 2016) & Mackerel & Scomber scombrus \\
\hline \multirow[t]{7}{*}{ Drumhiller et al. (2014) } & Red snapper & Lutjanus campechanus \\
\hline & Annular seabream & Diplodus annularis \\
\hline & Blotched picarel & Spicara maena \\
\hline & Brown comber & Serranus hepatus \\
\hline & Red mullet & Mullus barbatus \\
\hline & Mediterranean scaldfish & Arnoglossus laterna \\
\hline & Common pandora & Pagellus erythrinus \\
\hline Düzbastilar et al. (2010b) & Brown comber & Serranus hepatus \\
\hline Düzbastilar et al. (2015) & Red mullet & Mullus barbatus \\
\hline \multirow[t]{3}{*}{ (Düzbastılar et al. 2016) } & Solenette & Buglossidium luteum \\
\hline & Mediterranean scaldfish & Arnoglossus laterna \\
\hline & Spotted flounder & Citharus linguatula \\
\hline \multirow[t]{9}{*}{ Falterman and Graves (2002) } & Albacore & Thunnus alalunga \\
\hline & Bigeye tuna & Thunnus obesus \\
\hline & Dolphinfish & Coryphaena hippurus \\
\hline & Gempylids & Alepisaurus spp. \\
\hline & Longbill spearfish & Tetrapturus pfluegeri \\
\hline & Oilfishes & Ruvettus sp. \\
\hline & Sailfish & Istiophorus platypterus \\
\hline & Wahoo & Acanthocybium solandri \\
\hline & Yellowfin tuna & Thunnus albacares \\
\hline \multirow[t]{9}{*}{ Gisbert and López (2008) } & Big-scale sand smelt & Atherina boyeri \\
\hline & Common bleak & Alburnus alburnus \\
\hline & Common goby & Pomatoschistus microps \\
\hline & Common rudd & Scardinius erythrophthalmus \\
\hline & Eastern mosquitofish & Gambusia holbrooki \\
\hline & Flathead grey mullet & Mugil cephalus \\
\hline & Golden grey mullet & Liza aurata \\
\hline & Ironfishes & Carassius sp. \\
\hline & Spanish toothcarp & Aphanius iberus \\
\hline
\end{tabular}




\begin{tabular}{|c|c|c|}
\hline Reference & Species & Scientific names \\
\hline & Thinlip mullet & Liza ramada \\
\hline $\begin{array}{l}\text { Humborstad and Mangor-Jensen } \\
\text { (2013) }\end{array}$ & Cod & Gadus morhua \\
\hline Humborstad et al. (2016) & Cod & Gadus morhua \\
\hline Huse and Vold (2010) & Mackerel & Scomber scombrus \\
\hline Hyvärinen et al. (2008) & Pike-perch & Sander lucioperca \\
\hline \multirow[t]{3}{*}{ Ingólfsson and Jørgensen (2006) } & Cod & Gadus morhua \\
\hline & Haddock & Melanogrammus aeglefinus \\
\hline & Saithe & Pollachius virens \\
\hline \multirow[t]{3}{*}{ Ingólfsson et al. (2007) } & Cod & Gadus morhua \\
\hline & Haddock & Melanogrammus aeglefinus \\
\hline & Saithe & Pollachius virens \\
\hline (Jones 1993) & Hoki & Macruronus novaezelandiae \\
\hline \multirow[t]{3}{*}{ Jurvelius et al. (2000) } & Brown trout & Salmo trutta \\
\hline & Landlocked salmon & Salmo salar m. sebago \\
\hline & Pike-perch & Sander lucioperca \\
\hline \multirow[t]{11}{*}{ Kerstetter and Graves (2006a) } & Albacore & Thunnus alalunga \\
\hline & Bigeye tuna & Thunnus obesus \\
\hline & Escolar & Lepidocybium flavobrunneum \\
\hline & Great barracuda & Sphyraena barracuda \\
\hline & Lancetfishes & Alepisaurus spp. \\
\hline & Oilfish & Ruvettus pretiosus \\
\hline & Sailfish & Istiophorus platypterus \\
\hline & Snake mackerel & Gempylus serpens \\
\hline & Swordfish & Xiphias gladius \\
\hline & White marlin & Tetrapturus albidus \\
\hline & Yellowfin tuna & Thunnus albacares \\
\hline Kerstetter and Graves (2006b) & White marlin & Tetrapturus albidus \\
\hline Kerstetter and Graves (2008) & Sailfish & Istiophorus platypterus \\
\hline Kestin et al. (1991) & Rainbow trout & Oncorhynchus mykiss \\
\hline \multirow[t]{2}{*}{ Lambooij et al. (2012) } & Cod & Gadus morhua \\
\hline & Haddock & Melanogrammus aeglefinus \\
\hline Lockwood et al. (1983) & Mackerel & Scomber scombrus \\
\hline Lundin et al. (2012) & Herring & Clupea harengus \\
\hline \multirow[t]{2}{*}{ MacMillan and Roth (2012) } & Lake trout & Salvelinus namaycush \\
\hline & Walleye & Sander vitreus \\
\hline \multirow[t]{8}{*}{ Mapleston et al. (2008) } & Blackbloth emperor & Lethrinus semicinctus \\
\hline & Blue spotted rock cod & Cephalopholis cyanostigma \\
\hline & Coral trout & Plectropomus leopardus \\
\hline & Crimson snapper & Lutjanus campechanus \\
\hline & Red emperor & Lutjanus sebae \\
\hline & Redthroat emperor & Lethrinus miniatus \\
\hline & Saddletail snapper & Lutjanus malabaricus \\
\hline & Trevallies & Carangidae \\
\hline \multirow[t]{3}{*}{ Marçalo et al. (2008) } & Chub mackerel & Scomber japonicus \\
\hline & Jack mackerel & Trachurus picturatus \\
\hline & Sardine & Sardina pilchardus \\
\hline Marçalo et al. (2010) & Sardine & Sardina pilchardus \\
\hline McLennan et al. (2014) & Pink snapper & Pagrus auratus \\
\hline Milliken et al. (1999) & Cod & Gadus morhua \\
\hline Milliken et al. (2009) & Cod & Gadus morhua \\
\hline
\end{tabular}




\begin{tabular}{|c|c|c|}
\hline Reference & Species & Scientific names \\
\hline Misund and Beltestad (1995) & Herring & Clupea harengas \\
\hline \multirow[t]{3}{*}{ Misund and Beltestad (2000) } & Horse mackerel & Trachurus trachurus \\
\hline & Mackerel & Scomber scombrus \\
\hline & Saithe & Pollachius virens \\
\hline Mitchell et al. (2002) & South American pilchard & Sardinops sagax \\
\hline \multirow[t]{9}{*}{ (Morfin et al. 2017) } & European seabass & Dicentrarchus labrax \\
\hline & European hake & Merluccius merluccius \\
\hline & Whiting & Merlangius merlangus \\
\hline & Horse mackerel & Trachurus trachurus \\
\hline & Black seabream & Spondyliosoma cantharus \\
\hline & Gurnard & Triglidae \\
\hline & Pouting & Trisopterus luscus \\
\hline & Plaice & Pleuronectes platessa \\
\hline & Common sole & Solea solea \\
\hline \multirow[t]{2}{*}{ Olla et al. (1997) } & Sablefish & Anoplopoma fimbria \\
\hline & Walleye pollock & Theragra chalcogramma \\
\hline Olla et al. (1998) & Sablefish & Anoplopoma fimbria \\
\hline Olsen et al. (2012) & Herring & Clupea harengus \\
\hline Olsen et al. (2013) & Cod & Gadus morhua \\
\hline Orsi et al. (1993) & Chinook salmon & Oncorhynchus tshawytscha \\
\hline Pálsson Ó et al. (2003) & Cod & Gadus morhua \\
\hline \multirow[t]{6}{*}{ Pribyl et al. (2011) } & Black rockfish & Sebastes melanops \\
\hline & Blue rockfish & Sebastes mystinus \\
\hline & Canary rockfish & Sebastes pinniger \\
\hline & Quillback rockfish & Sebastes maliger \\
\hline & Yelloweye rockfish & Sebastes ruberrimus \\
\hline & Yellowtail rockfish & Sebastes ruberrimus \\
\hline Purbayanto et al. (2001) & Japanese whiting & Sillago japonica \\
\hline Raby et al. (2015) & Coho salmon & Oncorhynchus kisutch \\
\hline Ragonese and Morara (2012) & Blunthead puffer & Sphoeroides pachygaster \\
\hline \multirow[t]{4}{*}{ Rice et al. (2012) } & Billfishes & Istiophorus platypterus (mainly) \\
\hline & Blue marlin & Makaira nigricans \\
\hline & Bigeye tuna & Thunnus obesus \\
\hline & Swordfish & Xiphias gladius \\
\hline Richards et al. (1995) & Pacific halibut & Hippoglossus stenolepis \\
\hline Rudershausen et al. (2008) & Black sea bass & Centropristis striata \\
\hline Rudershausen et al. (2014) & Black sea bass & Centropristis striata \\
\hline \multirow[t]{14}{*}{ (Santos et al. 2017) } & Black marlin & Istiompax indica \\
\hline & Blue marlin & Makaira nigricans \\
\hline & Striped marlin & Kajikia audax \\
\hline & Sailfish & Istiophorus platypterus \\
\hline & Shortbill spearfish & Tetrapturus angustirostris \\
\hline & Swordfish & Xiphias gladius \\
\hline & Albacore & Thunnus alalunga \\
\hline & Bigeye tuna & Thunnus obesus \\
\hline & Yellowfin tuna & Thunnus albacares \\
\hline & Short snouted lancetfish & Alepisaurus brevirostris \\
\hline & Long snouted lancetfish & Alepisaurus ferox \\
\hline & Barracuda & Sphyraena spp \\
\hline & Medusafish & Centrolophidae \\
\hline & Dolphinfish & Coryphaena hippurus \\
\hline
\end{tabular}




\begin{tabular}{|c|c|c|}
\hline Reference & Species & Scientific names \\
\hline & Snake mackerel & Gempylus serpens \\
\hline & Opah & Lampris guttatus \\
\hline & Escolar & Lepidocybium flavobrunneum \\
\hline & Ocean sunfish & Mola spp. \\
\hline & Oilfish & Ruvettus pretiosus \\
\hline & Oarfish & Regalecidae \\
\hline & Wahoo & Acanthocybium solandri \\
\hline Smith and Scharf (2011) & Southern flounder & Paralichthys lethostigma \\
\hline Stachura et al. (2012) & Sablefish & Anoplopoma fimbria \\
\hline Stein et al. (2004) & Atlantic sturgeon & Acipenser oxyrinchus \\
\hline \multirow[t]{17}{*}{ Stephen and Harris (2010) } & Bank sea bass & Centropristis ocyurus \\
\hline & Black sea bass & Centropristis striata \\
\hline & Gag & Mycteroperca microlepis \\
\hline & Gray triggerfish & Balistes capriscus \\
\hline & Greater amberjack & Seriola dumerili \\
\hline & Red grouper & Epinephelus morio \\
\hline & Red porgy & Pagrus pagrus \\
\hline & Red snapper & Lutjanus campechanus \\
\hline & Sand perch & Diplectrum formosum \\
\hline & Sand tilefish & Malacanthus plumeri \\
\hline & Scamp & Mycteroperca phenax \\
\hline & Snowy grouper & Epinephelus niveatus \\
\hline & Tomtate & Haemulon aurolineatum \\
\hline & Vermilion snapper & Rhomboplites aurorubens \\
\hline & White grunt & Haemulon plumeiri \\
\hline & Yellow fin grouper & Mycteroperca venenosa \\
\hline & Yellowtail snapper & Ocyurus chrysurus \\
\hline Stewart (2008) & Snapper & Pagrus auratus \\
\hline Suuronen et al. (1996a) & Herring & Clupea harengus \\
\hline Suuronen et al. (1996b) & Cod & Gadus morhua \\
\hline Suuronen et al. (1996c) & Herring & Clupea harengus \\
\hline Suuronen et al. (2005) & Cod & Gadus morhua \\
\hline Tenningen et al. (2012) & Herring & Clupea harengus \\
\hline Turunen et al. (1994) & Brown trout & Salmo trutta \\
\hline \multirow[t]{2}{*}{ (Uhlmann et al. 2016) } & Sole & Solea solea \\
\hline & Plaice & Pleuronectes platessa \\
\hline \multirow[t]{2}{*}{ Van Beek et al. (1990) } & Plaice & Pleuronectes platessa \\
\hline & Sole & Solea solea \\
\hline Vander Haegen et al. (2004) & Chinook salmon & Oncorhynchus tschawytscha \\
\hline Willis and Millar (2001) & Snapper & Pagrus auratus (Sparidae) \\
\hline \multirow[t]{3}{*}{ Wilson Jr and Burns (1996) } & Gag & Mycteroperca microlepis \\
\hline & Red grouper & Epinephelus morio \\
\hline & Scamp & Mycteroperca phenax \\
\hline Yergey et al. (2012) & Summer flounder & Paralichthys dentatus \\
\hline
\end{tabular}




\section{Appendix D}

\begin{tabular}{|c|c|c|c|c|}
\hline & \multicolumn{4}{|c|}{ Injuries when using: } \\
\hline & Trawls & Hooks & Purse seines & Traps \\
\hline \multicolumn{5}{|l|}{ Gear characteristics: } \\
\hline \multirow[t]{3}{*}{$\overline{\text { Gear subtype }}$} & \pm (Digre et al. 2010) & \pm (Falterman and Graves 2002, Kerstetter and & & \\
\hline & 0 (Digre et al. 2010) & $\begin{array}{l}\text { Graves 2006a, Kerstetter and Graves 2006b, } \\
\text { Mapleston et al. 2008, Orsi et al. 1993, Rice et } \\
\text { al. 2012, Willis and Millar 2001) }\end{array}$ & & \\
\hline & & $\begin{array}{c}0 \text { (Kerstetter and Graves 2006a, Mapleston et al. } \\
\text { 2008, Rice et al. 2012) }\end{array}$ & & \\
\hline \multirow[t]{2}{*}{ Gear size } & & $+\quad$ (Mapleston et al. 2008) & & \\
\hline & & 0 (Mapleston et al. 2008) & & \\
\hline \multicolumn{5}{|l|}{ Fish characteristics: } \\
\hline \multirow[t]{2}{*}{ Fish length } & + (Suuronen et al. 2005) & - (Mapleston et al. 2008, Pálsson Ó et al. 2003) & - (Raby et al. 2015) & \\
\hline & $\begin{array}{c}0 \quad \text { (Ingólfsson and Jørgensen 2006, } \\
\text { Jones 1993, Suuronen et al. 1996b) }\end{array}$ & 0 (Mapleston et al. 2008) & & \\
\hline Fish species & $\begin{array}{l} \pm \text { (Depestele et al. 2014, Digre et al. } \\
\text { 2010) }\end{array}$ & \pm (Pribyl et al. 2011) & & \\
\hline \multicolumn{5}{|l|}{ Context variables: } \\
\hline $\begin{array}{l}\text { Change in water } \\
\text { temperature }\end{array}$ & & & & $\begin{array}{ll}+ & \text { (Colotelo et al. 2013) } \\
0 & \text { (Colotelo et al. 2013) }\end{array}$ \\
\hline Capture depth & + (Bottari et al. 2003) & $\begin{array}{l}+\quad \text { (Drumhiller et al. 2014, McLennan et al. 2014, } \\
\text { Pálsson Ó et al. 2003, Pribyl et al. 2011, } \\
\text { Stephen and Harris 2010) } \\
0 \quad \text { (Campbell et al. 2014) }\end{array}$ & & $\begin{array}{l}+ \text { (Rudershausen et al. } \\
\text { 2008) }\end{array}$ \\
\hline Fishing duration & + (Bottari et al. 2003) & & & $\begin{array}{l}+ \\
0\end{array}$ \\
\hline Density in the net & $\begin{array}{l}+\quad \text { (Bottari et al. 2003, Digre et al. 2010) } \\
\text { - } \quad \text { (Digre et al. 2010) }\end{array}$ & n.a. & & \\
\hline $\begin{array}{l}\text { Species composition } \\
\text { in the net }\end{array}$ & \pm (Bottari et al. 2003) & n.a. & & \\
\hline Boarding procedure & & & \pm (Candy et al. 1996) & \\
\hline
\end{tabular}




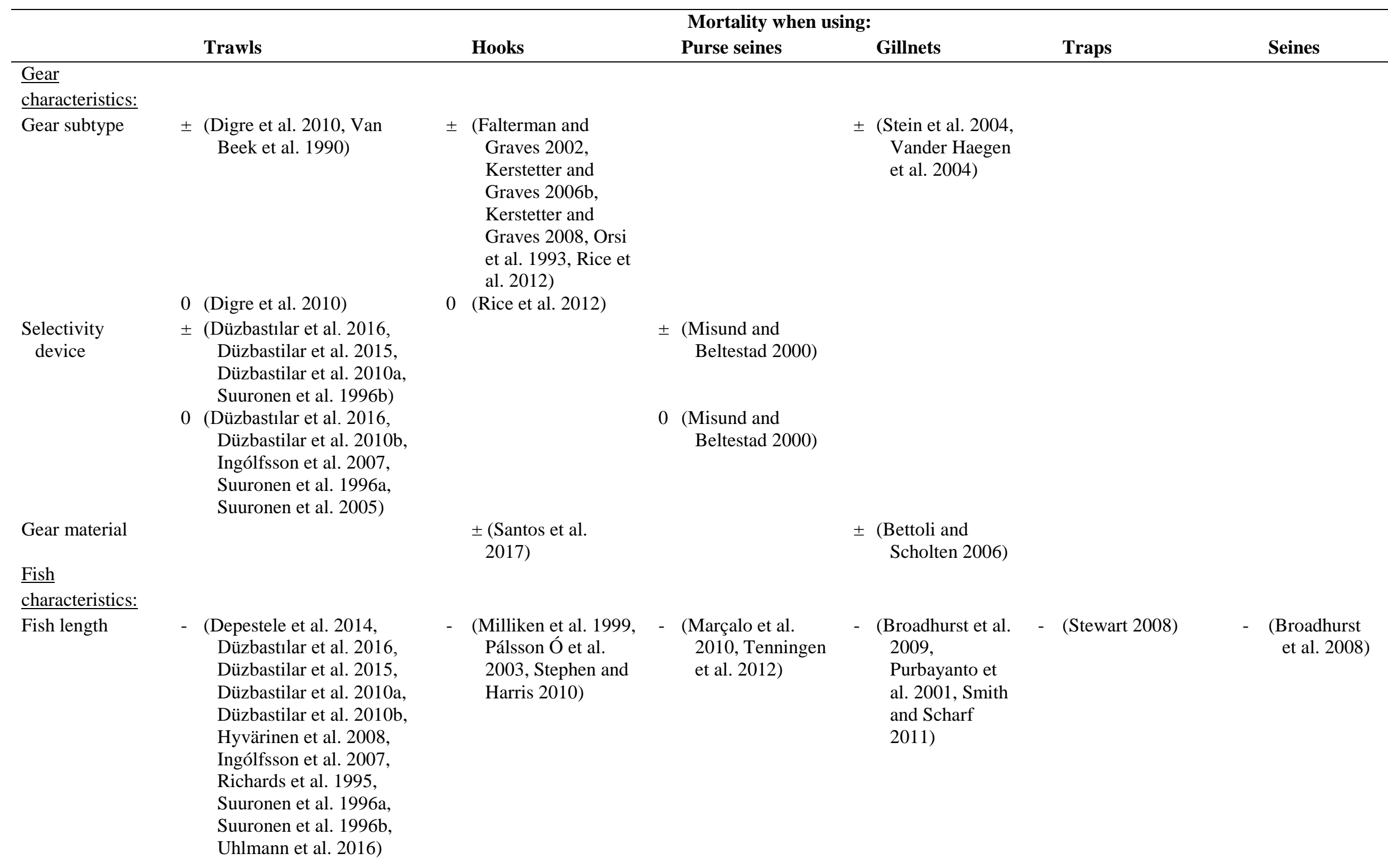




\begin{tabular}{|c|c|c|c|c|c|c|c|c|c|c|c|c|}
\hline & \multicolumn{12}{|c|}{ Mortality when using: } \\
\hline & & Trawls & & Hooks & & Purse seines & & Gillnets & & Traps & & Seines \\
\hline & 0 & $\begin{array}{l}\text { (Düzbastilar et al. 2010a, } \\
\text { Suuronen et al. 2005) }\end{array}$ & 0 & $\begin{array}{l}\text { (Kerstetter and } \\
\text { Graves 2006a, } \\
\text { McLennan et al. } \\
\text { 2014, Stachura et } \\
\text { al. 2012, Stephen } \\
\text { and Harris 2010) }\end{array}$ & 0 & (Candy et al. 1996) & 0 & $\begin{array}{l}\text { (Bettoli and } \\
\text { Scholten 2006, } \\
\text { Broadhurst et } \\
\text { al. 2009) }\end{array}$ & + & (Lundin et al. 2012) & 0 & $\begin{array}{l}\text { (Broadhurst } \\
\text { et al. 2008) }\end{array}$ \\
\hline Fish species & \pm & $\begin{array}{l}\text { (Davis 2007, Digre et al. } \\
\text { 2010, Jurvelius et al. } \\
\text { 2000, Morfin et al. 2017, } \\
\text { Olla et al. 1997) }\end{array}$ & \pm & $\begin{array}{l}\text { (Falterman and } \\
\text { Graves 2002, } \\
\text { Santos et al. 2017) }\end{array}$ & & & \pm & $\begin{array}{l}\text { (Broadhurst et } \\
\text { al. 2009) }\end{array}$ & \pm & $\begin{array}{l}\text { (Gisbert and López } \\
\text { 2008) }\end{array}$ & \pm & $\begin{array}{l}\text { (Broadhurst } \\
\text { et al. 2008) }\end{array}$ \\
\hline \multicolumn{13}{|l|}{$\underline{\text { Context }}$} \\
\hline $\begin{array}{l}\text { Change in water } \\
\text { temperature }\end{array}$ & + & $\begin{array}{l}\text { (Davis and Olla 2001, Davis } \\
\text { et al. 2001, Düzbastilar et } \\
\text { al. 2016, Hyvärinen et al. } \\
\text { 2008, Olla et al. 1998, } \\
\text { Suuronen et al. 2005, } \\
\text { Uhlmann et al. 2016, Van } \\
\text { Beek et al. 1990) }\end{array}$ & + & $\begin{array}{l}\text { (Davis and Olla } \\
\text { 2001, Davis et al. } \\
\text { 2001, Milliken et } \\
\text { al. 2009) }\end{array}$ & + & $\begin{array}{l}\text { (Marçalo et al. } \\
\text { 2010, Marçalo et } \\
\text { al. 2008) }\end{array}$ & + & $\begin{array}{l}\text { (Bettoli and } \\
\text { Scholten 2006, } \\
\text { Broadhurst et } \\
\text { al. 2009) }\end{array}$ & + & $\begin{array}{l}\text { (MacMillan and } \\
\text { Roth 2012) }\end{array}$ & & \\
\hline & 0 & $\begin{array}{l}\text { (Jurvelius et al. 2000, } \\
\text { Turunen et al. 1994) }\end{array}$ & & & & & 0 & $\begin{array}{l}\text { (Broadhurst et al. } \\
\text { 2009) }\end{array}$ & 0 & $\begin{array}{l}\text { (Dieterman et al. } \\
\text { 2000) }\end{array}$ & & \\
\hline Capture depth & + & $\begin{array}{l}\text { (Depestele et al. 2014, } \\
\text { Ingólfsson et al. 2007, } \\
\text { Jurvelius et al. 2000, } \\
\text { Richards et al. 1995) }\end{array}$ & + & $\begin{array}{l}\text { (Drumhiller et al. } \\
\text { 2014, Milliken et } \\
\text { al. 2009, Pálsson Ó } \\
\text { et al. 2003, } \\
\text { Stachura et al. } \\
\text { 2012, Wilson Jr } \\
\text { and Burns 1996) } \\
\text { (McLennan et al. } \\
\text { 2014) }\end{array}$ & & & + & $\begin{array}{l}\text { (Basaran and } \\
\text { Samsun 2004) }\end{array}$ & + & $\begin{array}{l}\text { (MacMillan and } \\
\text { Roth 2012, } \\
\text { Rudershausen et } \\
\text { al. 2008, Stewart } \\
\text { 2008) }\end{array}$ & & \\
\hline Fishing duration & + & $\begin{array}{l}\text { (Barkley and Cadrin 2012, } \\
\text { Davis 2007, Uhlmann et } \\
\text { al. 2016, Van Beek et al. } \\
\text { 1990) }\end{array}$ & + & $\begin{array}{l}\text { (Kerstetter and } \\
\text { Graves 2006a) }\end{array}$ & + & $\begin{array}{l}\text { (Candy et al. 1996, } \\
\text { Digre et al. 2016, } \\
\text { Lockwood et al. } \\
\text { 1983, Marçalo et } \\
\text { al. 2010, }\end{array}$ & + & $\begin{array}{l}\text { (Bettoli and } \\
\text { Scholten 2006, } \\
\text { Buchanan et al. } \\
\text { 2002) }\end{array}$ & & & & \\
\hline
\end{tabular}




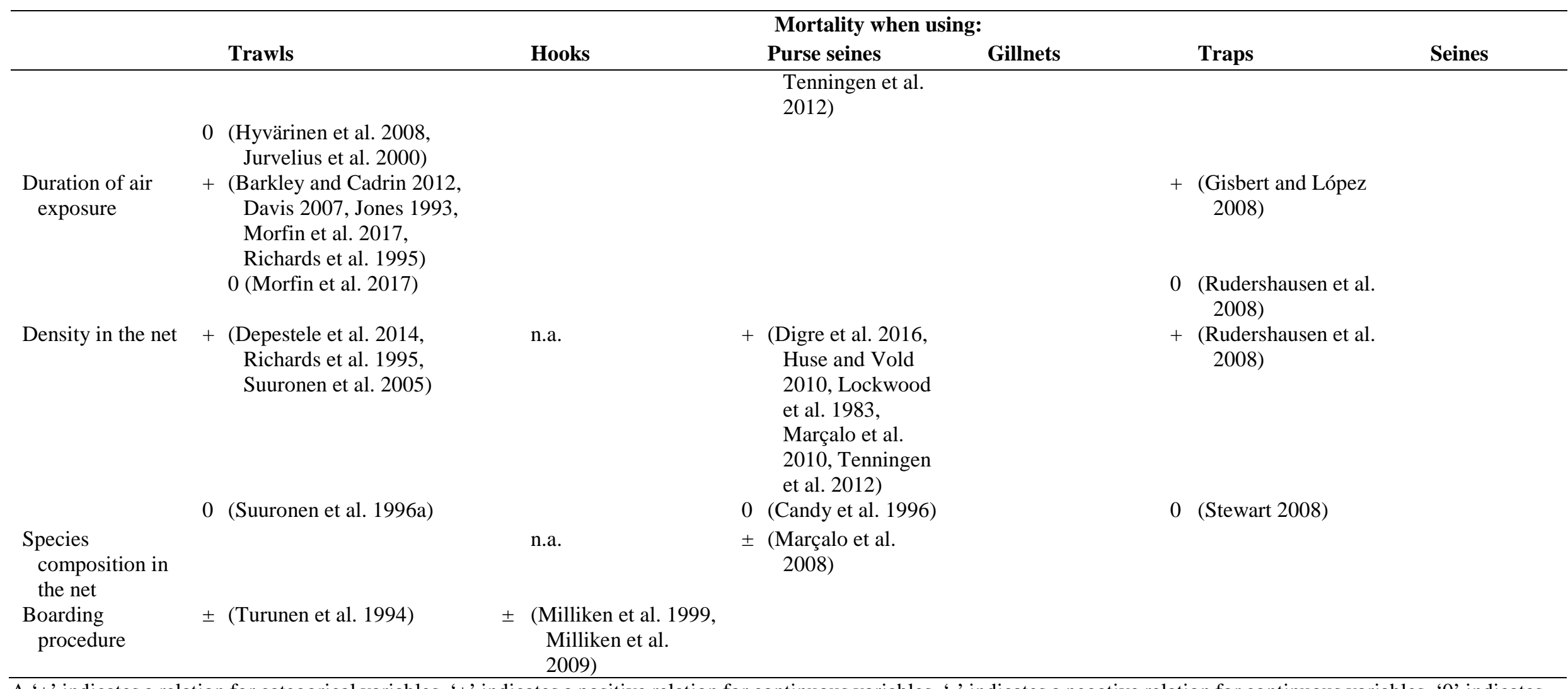

A ‘ \pm ' indicates a relation for categorical variables, ‘+’ indicates a positive relation for continuous variables, '-’ indicates a negative relation for continuous variables, '0’ indicates no relation, 'n.a.' indicates that such a relation is not applicable and an empty cell indicates to no information was identified in the literature reviewed 